\title{
HUKUK VE CEZA HUKUKU BILIMININ KONUSU VE SINIRLARI SORUNU
}

\author{
Dr. Zeki HAFIZOĞULLARI
}

1. Giriş, 2 . Hukuk ve ceza hukuku biliminin konusu, 3 . Kural ve kuralda kurallaştırılan, 4. Normatif ënermelerin temel niteliği, 5 . Hukukîformalizm, a) Hukuki formalizmde hukuk düzeni bir üstyapı kurumudur, b) Hukukun formel teorisi-hukukun normatif teorisi, c) Formel bilimler ve hukuk-ceza hukuku bilimi, d) $\mathrm{Hu}-$ kukun genel teorisi formel bir bilim midir, 6) Hukuk, daha özelde ceza hukuku normunun deneyselliği sorunu, a) Hukuk, ceza hukuku bilimi en son tahlilde deneye dayalıdır, b) Hukuk, ceza hukuku biliminde deneyselliğin sinırı, 7 . Pozitif hukukun teorisi olarak hukukun normatif teorisinin bilimliği sorunu, 8 . Sonuç.

1. Giriş.

Hukuk, ceza hukuku biliminin konusu, bilimlik değeti, sınılan halen doktrinde tartışmalı bir konudur. Bu araştırmada kısaca bu konular üzerinde durulacaktır.

\section{Hukuk ve ceza hukuku biliminin konusu*1.}

Hukuk daha özel olarak ceza bukuku, başlıbașına bir hayattır, toplumsal bir olgudur, hatta bu olgular içerisinde en önemli olanıdır. O nedenle, hukuk olgusu, tüm öteki olgular gibi deģişik açılardan ele alınıp incelenebilmektedir². Söz konusu olgu, bu çogulcı görünümün-

* Bu makalenin basımı sırasında Keyman, Hukuka giriş ve metodoloji, Ankara, 1981 adlı eser henüz çıkmamış olduğundan eserden yararlanmak mümkün olmamıştır.

1 Ceza hukuku bilimi, bazı özellikleri de olsa, hukuk bilimi dişında dūşünölemez. 0 nedenle bu araştırmada bütün ele alınmış ve bu bütünde genelden özele inilmiştir. Bu tür bir çalışmanin sonucu olarak hukuk ve ceza hukuku deyimiyle genelle birlikte özel de ifade edilmek istenmiștir.

- Perassi, Introduzione alle scienza giuridiche, padova, 1967, s. 22 vd: Düşünür, hukuk düzeninin degişik bakıs açıları altında farklı hukuk bilimlerinin konusu olabileceğini ortaya koymuştur. Bu nedenle bir hukuk biliminden deģil, hukuk bilimlerinden söz etmek gerekmektedir. Ancak bu bilimler arasında münhasıran hukukçuya ait olan alan, hukukun genel teorisi ve hukuk dogmatigi alanidır (s. 26 vd). Hukuk dogmatił̧i alanına, bundan böyle hukukun özel disiplinleri veya hukuk bilimi diyecegłz. Hukukun genel teorisi, doktrinde aksi de söylenmiş olmakla birlikte, hukukun bir tür felsefesi degil, hukukun kendisi, yani salt hukuktur; dolayısiyle belli bir hukuk sis- 
de bir de normatif bir açıđan incelenebilmektedir. Normatif bakış açısandan hukukun konusu sorunu, çözümünü, beșeri davranış kurallarinda bulmaktadır, çünkü davranışlar hukukta normatif önermelerde ifade edilmektedirler. Gerçekten hukuk kuralları normatif birer önermedirler. Bu, hukuk, ceza hukuku biliminin konusunun, ölçülen, denenen, gözlenen olay, olgu ve eylemlerin değil, ama bunlardan tamamen farkh bir varlığa sahip bulunan davranıs kurallarmın, yani normatif önermelerin, açıkçası normların olması anlamına gelmektedir ${ }^{3}$.

Hukuk, ceza hukuku bilimi, demek ki davranışlanın bizzat kendilerini değil, fakat onları düzenleyen kuralları, yani gerçekte gerçekleșip gerçekleşmemelerinden bağımsız olarak bir kısım davranışların nasıl düzenlenmiş olduklanını incelemektedir. Iște bu nitelikten ötürü hukuk bilimi; bizzat davranıslan incelemeyi konu edinen bilimlerden ayrıldığı gibi, incelenmiş davranışlardan kurallar çıkaran bilimlerden de ayrılmaktadır. Zira bu sonuncular, incelenen davranışların doğrı bir teșkilini konu edindikleri halde, hukuk bilimi, davranıs kurallarının bizzat kendilerini konu edinmektedir. ${ }^{5}$. Öleyse, hukuk bilimi, davranışları đavranıs olarak inceleyen bir bilim olmadığı gıbi, doğal veya beşeri bir gerçeklikten hareket ederek uyulması zorunlu bazı davranış kuralları saptayan bir bilim de değildir, çünkü davianıs kuralları, hukuk araștırmalarının, yani hukuk bilgisinin bir sonucu değil, sadece konu-

teminin degil, genel olarak pozitif hukukun bir teorisidir (Kelsen, Lineamenti di dottrina pura del diritto, Torino, 1967, s. 47; Bobbio, Studi sulla teoria generale del diritto, Torino 1955, s. 7). Hukuk felsefesi değerler aleminde faaliyet göstermektedir ve faaliyetinin üreünŭ degerlendirmedir. Hukukun genel teoriși kavramlar alanında faaliyet gösterir ve ürün olarak kuramsal önermeler ortaya koyar (Bobbio, Teoria della scienza giuridica, Torino, 1950, s. 12). Bù konuda bkz. Çăğ1l. Hukuk metodolojísi dersleri, Istanbul 1952, s. 141 vd.

3 Bobbio, Teoria della scienza, s. 162 ; Kelsen, Lineamenti, s. 5t ; Manzini, Trattato di diritto penela italiano, Torino, 1934, V. I, s. 1 vd.; Antolisei, Manuale didiritto penala, PG, Milano, 1963, s. 14-15; Toroslu, Cürümlerin tasnifi bakımından suçun hukuki konusu, Ankara, 1970, (giriş) passim; Kunter, Muhakeme hukuku dalı olarak ceza muhakemesi hukuku, lstanbul, 1978, s. 3 vd.

1 Bobbio, Teoria della scienza, s. 162.

5 Bobbio, Teoria đella scienza, s. 163 : Bu disiplinler arasinda dilbilgisi, edebiyat-san'at, siyaset vb. disiplinler sayılabilir. Gerçekten, dilbjlgisi đoğru konuşmada izlenecek kuralJarı , edebiyat-san'at, her ne kadar sanatçı kendi kurallarınt kendisi yaratırsa da, san'at yapmakta san'atçının izleyeceği kuralları; siyaset ise, devlet adamlarınin amaçlarma varmak için izleyebilecekleri temel kuralları saptamayı konu edinmektedir. Hukuk bilimi, bunlara nazaran bizzat beşeri davranişları inceleyen bir bilim olmadığ gibi, belli bir toplumsal veya đoğalı müşahadeden hareket ederek davranı̧ kuralları saptamayı amaçlayan bir bilim de degildir. Dilbilgisi hakkmnda bkz. Copi, Introduzione alla logica, Bologna, 1964, s. 40, 42 vd, 49, 346. 
sudur. $O$ nedenle hukuk bilimini öteki bilimlerden ayıran temel ölçütü burada aramak gerekiro.

\section{Kural ve kuralda kurallaştırılan}

Hukuk biliminin inceleme konusu madem beșeri davranış kurallarıdır, o halde bilinmesi gereken husus, bu kurallar karşısında hukuk-

- Bobbio, Teoria della scienza, s. 163. Ancak, bilmek gerekir ki, konumzunun özellikleri dolayısiyle hukuk bilimiyle ayniyet gösteren bir başka disiplin de, "ahlakî teoloji'dir. Ahlâkî teolojinin veya ahlâkın konusu, ahlâkı davranmada insanların nası̀ davranması gerektiợini saptamak amacı ile beșeri davranısıın ahlakî kurallarını incelemektir. Bu nedenle, hukuk bilimiyle ahlâkî teoloji arasındaki temel fark, birinin esas itibarıyla hukuku, ötekinin ahlâk kurallarını incelemesidir. Ancak, aradaki bu fark, iki farklı disiplinin metodolojileri arasındaki benzerlik, hatta ayniyet üzerine etken dełildir (Bobbio, Teoria della scienza, s. 164 vd) Bu nedenle her iki disiplinin benzer yönierinde bibiribirinden yararlanması doģaldır. Ancak bu, birinin öteki olduğo anlamına gelmez, çünkú, yukanda da belirtildi, her iki disiplinin inceleme konuları birbibirinden farklıdır. Ahlâk ve hukuk hakkında örneğin bkz. Ross, Diritto e giustizia, Torino, 1958, p. 12 ve krs. p. 7; Hart, II concetto di diritto, trad. di Cattaneo, Torino, 1956, Böl., 9; Kelsen, Lineamenti, Bö. II, p. 8-9; Del Vecchio, Hukuk felsefesi dersleri, Çev. S. Erman, Istanbul, 1952, s. 282-295; ID. II concetto del diritto, Bologna, 1912; Abadan Y. Hukuk Felsefesi derlseri, Ancakara, 1954, s. 90 vd.; Cobanoglu, Hukukta gaye problemi, Istanbul, 1964, s. 25 vd., 29 vd.; Aral, Hukuk ve hukuk bilimi üzerine, İstanbul, 1971, Kıs. I. p. 3; Güriz, Hukuk felsefesi, Ankara, 1975 s. 18 vd.

Ahlâkì teoloji ile hukuk arasındaki metodolojik benzerlik dolayısıyle "hukuk kurallannun ahlâkiliżi" veya "hukukun asgari ahlâk olduğu" yahut "nihai tahlilde hukưkun ahlâk-etik kökenli oldưgu" görüşleri üzerinde de kısaca durmak gerekmektedir. Doğru, hukuk da ahlâk gibi insanın doğadaki "pratik konumu alanında yer almaktadır (Bobbio, Introduzione alla filosofia del diritto, Torino, $1948 \mathrm{s.} \mathrm{32).} \mathrm{Ancak} \mathrm{bir} \mathrm{hukukun}$ ahlak olduğu anlamina gelmesez. Hukukun asgarî ahlâk oldugu görüşü, genellikle dinci, ahłâkçıı, tabî̀ hukukçu ve ahlâkçı ümanistlerce savunulmaktadır. Ayrıntılarında farkh ama esaslarında bir olan bu görüşler, șöyle ifade edilebilir: Ahlâk düzeni nasıl ki ilahi düzende yerini buluyorsa, tabiî tanrısız ahlâk anlayışını reddetmek gerekir, hukuk da ayn şekilde ahlâk dúzeninde yerini bulmaktadır (Maggiore, Diritto penale, PG., Bologna, 1961 V.I, TP., s. 16. Aynı dogrultuda, Cobanoglu, Hukukta yaga.., passim). Laik düşünūrler yönünden de durum hemen hemen ayndır. Bunlarda, hukuk, sonunda dine bağlanmamakta ve fakat ahlâk kendisiyle bağımlı kavramlara vücut veren nihai bir ideoloji olmaktadır. Bunun sonucu olarak, "adalet kavramı" ortaya çımakta ve hukuk "fonksiyonu açısından" görülerek sonunda ahlâka indirgenmektedir. Orneğin, Erem, Umanist doktrin açısından Türk Ceza Hukuku, GH, I, Ankara, 1971,

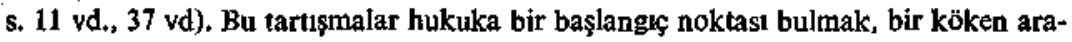
mak ihtiyaçından doğmaktadır. Bu konuda iki temel düşūnce akımıyla karş̧ karşıya bulunimaktayız. Bu akımlardan ilki hukukun kökenini din- ahlâkta bulan dūșūnceleriđir; karşıtı düşŭnce hukukun kökenini nesnede, ekonomide bulan düşünceleriđ̛̀i görüşler ve ayrıntıları için bkz. Croce, Filosofia della pratica, 6 ediz. 1950, Part III; ID. Riduzione della folosofia del diritto alla filosofia dell'economia, Napoli, 1962. Marksçı düşünüurler de hılkuku ekonomiye indirgemelctedirler: Marx-Engels, Opere scolte, Roma, 1966, s. 1242; Engels, Origine della famiglia della proprieta privata dello stato, Roma 1950; Salinari, Introduzione, In "Scritti sull'arte" Bari, 1967, s. 12 vd. 
çunun ne gibi bir tavır takındığıdır. Incelendiğinde, davraniş kuralları karş:sında hukukçunun biribirinden farklı iki tavır takımıldığı görülmektedir. Geıçekter, kural, sadece kural olarak, yani kendisinden hukukilik niteliği aldığı tüm davranışları içeren "tipik" bir normatif yapı olarak çözümlenir, ya da kuralın muhtevası, yani k uralda kurallaştırılan davranış çözümlenir. Ancak, burdara, ilkinki husus sağlanmış olmadıkça ikincinin sağlanması mümkün değildir, çünkü bir yapının muhtevasınının bilinmesi, bizzat yapının ne olduğunun bilinmesiyle bağımlıdır. İște, aralarında bağımlı bu iki faaliyetiten ilki, "hukukun genel teorisi" denilen disipline, öteki hukuk bilimi olarak bilinen ve kiminin doğmatik hukuk değdiği hukukun farklı disiplinlerine vücut vermektedir. Bu sonuncular da, kendi aralarında, geleneksel tasniflerinde olduğu gibi, kamu hukuku-özel hukuk ${ }^{8}$ veya daha özelde ceza hukuku, idare, anayasa, medeni hukuk vb. disiplinlere ayrilmaktadır'.

Gerçekten, karmaşıklğğ içerisinde gözönüne alındığında davranış kuralarında kural denilen yapı, kural olmasından, hukukî biçimi; buna karşılık bu yapıda kurallaştırılan, yani kuralda kurallaștırılan hukukun muhtevasını teşkil etmektedir. O halde, hukukun genel teorisi,

Bu konu ile ilgili olmak üzere ve geniş bibliyografya için bkz. Battaglia, Diritto e economia, Scritti giuridici in onore di F. Carnelutti, Padova, 1950, V.I, s. 195 vd.; Brunetti, Il diritto, la forza dello Stato e la morale, Pisa, 1918, s. 19 vd.; Umanizm hakkinda bkz. Lanza, Umanesim e il diritto penale, Catania, 1929.

Hukukun şu veya bu kökenden gelmiş olmașı veya şu veya buna bağtanması, kuramsal değil öyle sanıyoruz idolojık bir tartışmadır. Burada ideolojık bir tartışmaya girmek konumuzun sınırları dışındadır. Hukukun konusu normatif önermelerdir. Bizim için önemli olan da budur. Bu önermelerin şu veya bu kökenli olmaș, hiç olmazsa burada, araştırma konumuzla ilgili değildir. Kaldı ki, hukuk biliminin nasıl bir bilim olduğunu açıklamak için, onu, ahlâk yahut ekonomiye indirgemeye de gerek yoktur. Bu tür bir davranış, jdeolojik gereksinmelere cevap verse bile, hukuk biliminin özerkliği kaybolđuǧundan, sakıncalı sayilmak gerekir. Ancak, bu, hukukla ekononik yapı arasında bir bağıntının olmadığı anlamına alınmamak gerekir. Hukuk, ekonomik yapı ve ahlak arasında kuşkusuz bir bağıntı varâır. Fakat bu bağıntıyı incelemek, pozitif hukukun bir bilgisi olan hukuk bilimine düșmez (ayrıntılı bilgi için bkz. Manzini, Trattato, V.I, s. $22-35)$.

, Perassi, Introduzione, s. 26 vd. Toroslu da "hukuk doğmatiği" veya "doğmatik hukuk ilmi" terimlerini kullanmaktadır. (Toroslu, Cürümlerin, s. 4, 5 ve passim.) Önekler daha da çoğaltılabilir. Biz, hukuk önermelerinin hiç olmazsa nihaî tahlilde deneysel oldugunu varsaydığımızdan, (bkz. p. 6, a, b, c) hukuk doğmatigi terimi yerine, "hukık bilimi" terimini kullanacağı.

- Kamu hukuku-özel hukuk ayrımı halen doktrinde tartışmalı bir konu dur. Ancak, bugün, bu ayrımın genellikle kuramsal değil, didaktik bir değere sahip olduğu söylenmektedir. Kelsen, Lineamenti, s. 12.3 vd; Ross, Diritto e giustizia, s. 191-200; Akipek, JG., Türk međeni hukuku, Ankara, 1973, C. 1, Cüz. I, s. 10 vd; özellikle, s. 12-13; Göger, Hukuk başlangıcı dersleri, Ankara, 1972, s. $46 \mathrm{vd}$.

- Bobbio, Teoria della scienza, s. 166 
hukukun formel, yani hukukun bir biçim teorisidir. Buna karşılık, tüm disiplinleriyle hukuk bilimi, bir muhtevalar incelemesidir. Bu iki faaliyet, fiiliyatta biribirinden ayrı yürütülmekle birlikte, hukukun ve genelde özel ceza hukukunun eksiksiz bir bilgisi, ancak bu iki disiplinin bireșimi sonucu elde edebilmektedir ${ }^{10}$. Zira, bir kural olarak ele alınan kuralın biçimlik ögesinden hukuk normunun yap̧1sı, ișleyiși ve ortạtadan kalkışıyla ilgili araştırmalar doğarken, münferit modellerce teşkil olunan maddî ögeden kurallaştırılmış davranıșların belirlenmesi, tasnifi ve sistemleştirilmesi ile ilgili araştırmalar doğmaktadır. Öyleyse ilkinki husus, düzeninin nasıl teşkil ve terkip olduğu sorusuna, ikinci husus, kendisinden bir hukuk düzeni teşkil ve teı kip olunan kurallar bütününün neleri kurallaștırdığı sorusuna cevap vermektedir. Bu demektir ki, ilkinkiyle ilgili sorunlar yapılsal, buna karşılık ikinciyle ilgili sorunlar muhtevasal sorunlardur ${ }^{11}$.

Ancak, hukukun genel teorisi, hukuk normunun yapisal sorunlartnın çözümünü içerdiğinden, hukuk normu yapısı içinde yer alan muhtevasal sorunların sözümlenmelerini zorunlu kılmamaktadır. $O$ nedenle, hukukun genel teorisi, hukukun bir biçim teorisidiı denilmektedir. Bu da, hukukun genel teorisinin, mutlaka hukukun formel bir teorisi olduğu anlamına gelmektedir ${ }^{12}$.

Bobbio, Teoria della scienza, s. 167; ID. Studi sulla teoria generale del diritto, Torino, 1955; passim. Kelsen, Lineamenti, s. 47, 59 vd.

1. Bobbio, Teoria della scienza, s. 167.

12 Bobbio, Studi sulla teoria generale, s. VI vd, ve passim. Hukukun genel teorisinin hukukun bir biçim teorisi olduğg doktrinde tartışmasız kabul edilen bir düşünce değildir (örneğin, deşişik de olsa, Antolisei, Per un indrizzo realistico, nella scienza del diritto penale, Pavova, 1937, estratto della Riv. it. di. Dir. Pen. Anno, IX, 1937-XV, n. 2, s. 8, 14 vd. ve 28). thtilâf daha çok mantıki formalizim ile hukukî formalizmin eș tutulması üzerinde dügüumlenmektedir. Oysa bu iki terim, eş anlamlı değildir. Sonra, hukukụn formel teorisi. hukuk olgusunun incelenmesinde bilinen yegâne yol da değjidir. Kuşkusuz, başka bakış açıları đa vardır. Ancak, hangi etik-siyasî jdeolojide biçimlenirse biçimlensin, hukuk düzeninin ne olduğunu veya tüm hukuk sistemlerinde cari temel öğeleri incelemede, yegăne ama yegâne geçerli bakıs açısı, hukukun formel teorisidir (geniş bilgi için bkz. Babbio, Studi sulla teoria generale, Cap. IV). Hukukun formel teorisinin hukuk bilimini yozlaştıracağ, onu toplumsal gerçeklikten uzaklaştıracağı ve sonunda sait bir mantıkj formalizme indirgeyeceği görüşü tutarlı olmamak gerekir, çünkū hukukun bir biçim olarak incelenmesi, ne deģerlerin, ne de bir hukuk sisteminden önteki bir hukuk sistemine göre değișen tipik modetlerin (fattispecie) incelenmesine engel değildir. Öte yandan, kaltp yapma sanatı başka bir §ey, kalıbı doldurma sanatı basska bir şeydir. O nedenle, kalıp yapımcısını, ne kalıpları hep aynı şeyle doldurduğo ne de onları muhtevadan yoksun kıldığ yolunda eleştirmemek gerekir. Bu konuda hukukî formalizmle "etik formalizm'de biribirine karıştırılmamalıdır (Bkz. Bobbio, Studi sulla teoria generale, Cap. VII). "Etik formalizm, adelet kavramın kanuncu anlayışının (concezione legastica della giustizia) doktrinidir. Hukuki formalizm, adalet sorunuyla değil, hukukun biçimsel geçerliliłgi sorunuyla ilgilidir. $O$ nedenle, 


\section{Normatif onermelerin temel nitely}

Muhteva ögesi ve buna bağlı sorunlarin incelenmesi 'hukuk yorumu'nun konusu olmaktadır ${ }^{13}$. Ayrıntılarından çok çetin olan bu konu, burada, sadece hukuk önermelerinin temel karakterini saptama yönünden ele alınıp incelenecektir ${ }^{14}$.

Her hukuk kuralı, ileride de açılanacağı üzere, bir önermedir, çünkü kendisiyle her hangi bir şey ifade edilmektedir. Ancak, o, herhangi bir önerme değil, ödev kapsamlı bir önermedir. Ödev kapsamlı önermeler, normatif önermelerdirler. Hukuk biliminin konusu bu normatif önermeler arasında yer alan belli bir tür normatif önermelerdir. Bu ifadenin doğal sonucu, hukuk biliminin fiilletle değil, münhasıran fiiller üzerine önermelerle ilgili olduğudur ${ }^{1 s}$. Bu demektir ki, hukukçu, 'vak'aları müşahade etmemekte, aksine aracılığıyla vak'aları yeniden teşkille yükümlü olduğu bir kısım sözlerin anlamlarmı araştırmaktadır. Bu yönü nedeniyle hukuk bilimi doğa bilimlerinden ayrilmaktadır. Zira, doğa bilimlerinde müşahade, müşahade edilen bir münasebetin

etik formalist olmaksızın hukukì formalist kalarak iyi bir hukukçu olmak ve hukukî sorunlara yaklaşmak her zaman mümkün olmak gerekir (Bobbio, Studi sulla teoria generale, s. VII).

(3) Bobbio, Teoria della scienza, s. 168.

is Burada "hukuki yorum" terimiyle kastedilen hukuk ve ceza hukuku araştırmasında metodtur. Ancak, bu sorun, burada, sadece normatif önermelerin özellikleri yönünden ele alını inceienmiş ve bunun için de metod hakkında ayrıntılı bir incelmeye girilmemiştir. Hukuk ve ceza hukukunda metodla ilgili olarak Ör., bkz. Cammarata, Formalismo e sapere giuridico, Cappelli Editore, 1962; Sforza, Leggi giut idiche e leggi naturali, Rinv, int. Fil. Dir. 1959, s. 448 vd.; ID. Norma giuridica e struttura sociale, Riv. Int. Fil. Dir. 1960, s. 127 vd.; Trevers, Il metodo teleologico, s. 545 vd.; De Francisci, Dogn matica e storia nell'educazione giuridica, Riv. Int. Fil. Dir. 1923, F. IV; Antolisei, Per un indrizzo realistico (makale tümü jle); Grispigni, La dogmatica giuridjca e il moderno indrizzo nelle scienze criminali, Milano, 1920., Estratto della Riv. di. Dir.e proc. Pen.. 1920, F. 11-12; Rocco, Il Problema e il metodo della scienza del dirito penale, Riv. di dir. e proc. pen, 1910; Maggiore, La dottirina del metodo giuridico e la sua revisione, Riv. Int. Fil. Dir., 1926, s. 364 vd.; ID. Fuznzioni e limiti della dogmatica nella scienza del diritto ctiminale, Annali dell'universita di Perugia, 1924, V. VII-VIII; Spirito, La concezione tecnico-giuridica dell dirito penale, Nuovi Studi, 1929, s. 26 vd..; Santoro, Scienza giruidica e realta". Riv. It. di Dir. Pen., 1936, n. 5; Carnelutti, Nuove riflessioni intorno al metodo, scritti Giuridici in onore di A. De Marsico, Milano, 1960, V.I; Leone de Ugo, Il tecnicismo gitridico penale in una sua ultima formulazione, Riv. Int. Fil. Dir. 1951; Ferri, E., Principi di ïirtto criminale, Torino, 1928, s. 63 vd.; Petrocelli, Tecnicismo e antitecncismo nel diritto penale, Scritti giuridici in onare di F. Carnelutti, Padova, 1950, V. IV; Dönmezer-Erman Nazari ve tatbiki ceza hukuku, genel k1sım, I, İstanbul, 1473 (1976)., s. 54-118, 177-197; Erem, Ceza hukuku, UH. C. 1, (dolaylt da olsa) s. 1-21, 87-104; Toroslu, Cürümlerin, s. 1-18.

15 Bobbio, Teoria della scienza, s. 168-169. 
önermelerini temsil eden sözlerle açıklanmaktadır. Oysa hukuk ve ceza hukuku bilimi için sözler, bu türden önermeler olmayıp, sadece hukuk araştırmasının konusu olmaktadırlar. $O$ halde, hukuk biliminde, araştırma sonunda ortaya çıkan önermeler, araștırma konusu olan bir başka önermeler üzerine biçimlenmektedirler. Gerçekten, doğa bilim,lerinde dil, belli bir "müşahadeler bütününü", yani inceleme konusu yap1lan gerçekliği ifade eden bilimsel sistemi teşkil etmektedir. Ancak, hukuk bilimi alanınđa bu böyle olmamaktadır. Zira, dil, açıkcası kanun koyucunun veya kanunun sözleri, hukuk biliminde, hukukçunun bilimsel sistemini değil, fakat münhasıran hukuk biliminin konusunu teşkil etmektedir. O halde, hukukçunun bilimsel sistemi, bizzat hukukun dilinden değil, aksine bu dil üzerine teşkil olunan bir başka dilden doğmaktadır. Görüldüğü üzere, hukuk biliminde, gerçeklikle araştırma arasına belli bir gerçekliği ifade eden ve bizzat gerçekliğin araştırması olmayan, fakat gerçeklik üzerine belli bir yargıyı ifade eden bir dil girmektedir. O nedenle, hukuk ve cəza hukuku biliminde söz konusu olan gerçek, vak'aları bilmek deg̀il, fakat gerçeklik üzerine verilen bazı hükümlerin anlamlarını yorumlamaktır. Öyleyse doğa bilimlerinden farklı olarak hukuk bilimi, doğrudan doğruya gerçeklik üzerine bir dil değil, ama belli bir gerçeklik üzerinne kurulan belli bir dil üzerine bir dildir ${ }^{16}$.

Aricak, hukuk biliminin bu yorumsal karakteri, yani fiiller üzerine bir dil olma yerine, dil üzerine teşkil olunan bir dil olma özelliği, sadece kendisine özgü bir nitelik değildir, çünkü insanı manevi tezahürleri içerisinde inceleyen bütün bilimler, yani manevi bilimler aynı özelliğe sahiptirler ${ }^{17}$. Sembollerce ifade edilen beşeri düșüncenin anlatılan usulle bilinmesi eğer yorumsa, her halde tüm manevi bilimler bu anlamda yorumsaldırlar. Zira, bunlar da, vak'alara doğrudan dogruya değil, fakat yorumlanacak bir kısım önermeler a1acılığıyla nüfuz etmektedirler. Bu nedenle de, tüm manevi bilimler dilinin, vak'alar üzerine oluşmuş önermeler üzerine işlenmiş bir önermeler bütününden doğduğu söylenebilir. Durum bu olduğna göre, getirilen ölçüt, hukuk, ceza hukuku bilimini doğa bilimlerinden ayırmakla birlikte, onun manevi bilimler arasında ferdileştirilebilmesine imkân vermenektedir. Çünkü yorum, yani söz aracılığıyla fikkî muamelelerin kavranması veya simgeden simgece ifade edilene varma, hukuk bilimiyle manevi bilimletden sayllan öteki bütün bilimler arasında ortak bir yön olmaktadır ${ }^{18}$.

1* Bobbio, Teoria della scienza, s. 169.

17 Bobbio, Teoria della scienze, s. 170. Ayrica bkz. Abadan Y. Hukuk felsefesi, s. 26-33. Çă̆ıl1, Hukuk metodolojisi, s, 1-7.

(s) Bobbio, Teoria della scienza, s. 170 . 
Ancak yorumsallikları bakımından aralarında herhangi bir fark bulunımayan hukuk ve ceza hukuku bilimi, aralarında tasnif edildikleri manevi bilimlerden, inceleme konusunu teșkil eden dil veya önermeler bakımından farklılaşmaktadırlar. Zira hukuk biliminin konusunu teşkil eden önermeler, belli bir tip önermelerdirler, açıkası belli bir tip normatif önermelerdirler. İşte inceleme konusu önermelerin bellir bir tip normatif önermeler olması, hukuk biliminin manevi bilimler alanında feı dileştirilebilmesine imkân vermektedir. Buradan çıkanlabilecek başka bir sonuç, normatif önermelerin gerçeklik üzerine bir gerçeklik yargisı açıklamaması, aksine olması gerken üzerine bir önerme formülleștirmesi, yani gerçeklik üzerine bir deger yargısı ifade etmesidir. O halde her normatif önerme, clan alanına degil, fakat olması gereken alanına aittir. Bu temel niteliği nedeniyle normatif önermeler, ne olmuş veya olmakta olan vak'alarm bir 'tesbitini', ne de olması gereken şeylerin bir 'tahminini' formülleștirmektedirler, ve dolayısiyle sadece belirli bir kısım davranışları düzenlemektedirler. Öyleyse, araştırmalan inda bu önermeleri konu edinen hukuk, ceza hukuku bilimi, ne gerçek, nede muhtemel davranışlarla ilgilidir; ilgili olduğu davranışlar, "farazi davranışlar"dırlar. Bundan ötürï, davrantş̧lar gerçekliği karşısında norm -kural önerme, ne bir tesbittir, ne de bir tahmindir, sadece ve sadece bir "faraziye"dir".

Aralarınđa benzerlikler bulunmakla birlikte "farazi davranıslar" "muhayyel davranıșlar" değildirler. Aslında her iki davranış da gerçek davranţ̧ değildir, ama farazi davranışlar, daima olmuş veya olması muhtemel davranıșlara karş̧ılıkken, muahayyel davranıșların bu tür bir zorunluluğg yoktur. Başka bir deyimle, bu sonuncular, farazi davranışlardan farklı olarak, hiç bir gerçek davranışın karşılı̆̆ı olmayabilirler. Öyleyse, farazi davranışlar, daima ve her zaman 'mümkün davranışlar'dır. Bu demektir'ki farazi davranıșlar, münhasıran mümkün davranışlar olduklan için zorunlu olarak gerek gerçek davranışlardan ve gerekse olması mümkün olmayan gerçek dıșı veya farazî davranışlardan ayrılmaktaıđırlar. Bu neđenle de, davranışların ifadesi olan normatif kapsamlı ifadelerin, sadece ve sadece, imkânolasılık alanına ait oldukları söylenebilir. Bunun dogăl sonucu, hukuk alanının, gerek "gerçek davranışlar" alanı olan zorunluluk alanından gerekse "fantazi davranışlar" alanı olan olmazlık alanından ayrılmasidır ${ }^{20}$.

Hukuk ve ceza hukuku biliminin "varolmalı ifađeleri" değil, fakat "normatif ifadeleri" konu edinmesi görüldüğü üzere kendisi gibi

Bobbio, Teoria della scienza, s. 171

so Bobbio, Teoria della Scienza, s. 171-172. 
yorumsallı gösteren diger manevi bilimlerden onu ayırmada esas ölçü olmaktadır. Gerçekten, yorum eylemi, en genel anlamına, yani simgeden simgece ifade edilene götürülürse, hukuk bilimiyle öteki insan bilimleri arasındaki temel farkı saptamak mümkün olmamaktadır. Ancak, daha özele inilerek gerçekliğe gitmedeki çeşitli biçim ve yollar göz önüne alınırsa, bu farkı saptamak hiç kuşkusuz mümkün olabilmektedir. Şöyle ki, manevi bilimlerin, örneğin tarihin konusu, münhasiran "varolmalı önermeler"dir, Buna karș1lık, hukuk, ceza hukuku biliminin konusu, normatif önerlemelerdir' Burada, 'varolmalı önermeler' betimlemeler alanına, buna karşılık 'normatif önermeler' yaptırmalar veya emirler alanina aittirler ${ }^{21}$. Iște, bu nedenle, manevi bilimlerde, örnegin tarih bilimlerinde, belgelerin yorumu suretiyle bir vak'a yeniden inşa edilirken, hukuk ve ceza hukuku biliminde, hukuk kuralları veya normlarının yorumu suretiyle belli bir fiil veya fïllerin düzenlenmesi yeniden inşa edilmektedir. Böylece, gerçekliğe gitme biçimi, bu bilimlerde biribirinden farklı olmaktadır: Hukuk biliminin uğraştı̆̆g fïller, tarih bilimlerinin aksine, gerçek fiiller değil, fakat normatif ifadelerde ifadesini bulan mümkün fiillerdir. $O$ halde, tarihçi, yorumla gerçek alanına, buna karşılık hukukçu, imkân alanına nüfuz etmeye çalışmaktadır. Bu iki farklı tavrın sonucu olarak, tarihçi olana ulaşır; hukukçu olması gerekende kalır. Işte hukuk bilimini bütünde bireyleştirebilen bu kendine özgü niteliği, onu her halde hem aralarında tasnif edildiği manevi bilimlerden, hem de doğa bilimlerinden ayırmada tek geçerli ölçüt olmaktadır ${ }^{22}$.

Ancak, hukuk biliminin bu kendine özgülüğü, onun öteki bilimlerden ayrılmasını sağlamakla birlikte, nasıl bir bilim olduğu sorusunu gereğince açıklayamamaktadır. Zira, yorumsallıkta kendisi ile ortak olan manevi bilimler, aslında bakılırsa doğa bilimleri gibi deneysel bilimler sayılmaktadırlar. Şu farkla ki, manevi bilimlerde, örnegin tarih bilimlerinde, konusu şeye, doğa bilimlerinin aksine, doğnudan doğruya değil, ancak belgelerin yorumu, yani işaret veya simgelerin kavranmast suretiyle nüfusz edilmektedir. Ama, burada, nesnenin doğal gerçekliği değil insanın manevi gerçekliği olan asıl konuya bir kere girildi mi, bundan sonra, artık manevi bilimlerle, örneğin tarih bilimleriyle, doğa bilimleri arasında esasta hərhangi bir fark ortaya çıkmamaktadır, çünkü her iki grup bilimde de anlatım, varolmalı karakterde önermelerle sağlanmakta ve sonunda gelecek için tahminlerde bulunuimaktadır.

2) Dilin yapturma görevi ve normatif önermeler hakkında bkz. Bobbio, Teoria della nornorma, s. 71-122; Copi, Introduzione, Capitolo seconde; Baturhan - Grünberg, Modern mantuk, İstanbul, 1973, Bö. I.

22 Bobbio, Teoria della scienza, s. 173. 
Başka bir deyimle, gerek tarih ve gerekse doğa bilimleri, "bu ve öteki gerçeklești, öyleyse bu esasa göre, bu ve bu öteki gerçekleșecektir" demektedirler ${ }^{23}$.

Oysa, bu durum, hukuk billimi için söz konusu olmamaktadır. Hukuk biliminde, ne olan saptanmaktadır, ne de olacak tahmin edilir, çünkü hukuk biliminin konusu, olan değil, olması gerekendir. Bu nedenle hukukçuyu ilgilendiren, olana (geçmiş, hal ve gelecek) ait bir şey değil, fakat münhasıran olması gerkene ait bir şeydir. Hukuk bilimin.de ne 'A sonucu gerçekleşti' ne de 'A sonucu gerçekleşecek veya gerçekleşebilecektir' denmektedir. Anlatım 'A gerçekleșmelidir' biçimindedir. Burada A'nın gerçekleşeceği veya gerçekleșmeyeceği, gerçekleştiği yahut gerçekleşmediği, artık hukuk biliminin değil, ama bir başka bilimin, bir başka anlatımın konusu olmaktadır ${ }^{24}$.

Söylenenlerden, hukuk, ceza hukuku biliminin, konusunu teşkil eden normatif önermelerin esas karakterinden ötürü, deneysel bir bilim olmadığ, bunun bir sonucu, doga ve tarih bilimlerinden farkının oturduğu temelin deneye dayalı olmadığı, şu halde hukukun deneye ihtiyacı olmayacağı sonucu çıkarlabilir. Ancak, bu konuda kesin bir sonuca varılmak isteniyorsa, öncellikle biribirinden farklı iki konuyu bir açıkhğa kavuşturmak gerekmektedir. Hukuk bilimi gerçekten "formel bir bilim" midir, yoksa en son tahlilde deneye mi dayanmaktadır?

\section{Hukuki formalizm}

Hukukî formalizm, 'denilebilir ki, ilk kez Stamler tarafindan ortaya konulmuşs

23 Bobbio, Teoria della scienza, s. 174: Ancak, tarih bilimleri, kontlarının azami karmaşık şik olması nedeniyje genellikle gelecek için tahminlerde buluntmaktan kaçınmaktadırlar. O nedenle, tarihçi, olanı anlatmak ve olan üzerine yargı vermekle yetinmektedir (s. 174). Her halde bu nedenle, "illi - gai" bilimler" tasnifinde, deneyselligine rašmen tarih bilimlerine, gai bilimler arasında yer verilmektedir Bkz. Çẳll, Hukuk metodolojisi, s. 18 vd. 26 vd.

24 Bobbio, Teoria della scienza, s. 174.

25 Stamler'e göre, toplum kavramundan, ortak amaçlara varmak için faaliyet gösteren belli bir insan grubunun amaçlarıyla bağımlı bir birlik anlaşılmak gerekir. Bu kavramda saklı iki ayrı unsur kesinlikle biribirinden ayrılmalıdır. Bunlardan biri, ortak hayatın şartlandıran biçiminde saklı ve harici bir kuralla ifade edilen baǧımlılık olarak bağ, öteki, tüm diģer beșeri faaliyetler gibi belli ihtiyaçların tatminine yönelen aralarında bağgtmlt fertierin uyuşan faaliyetleridir. Iş̧te toptumu teşkil eđen bu iki unsur, mantıken aynı dũzeyde degildirler. Birinci ötekinin mantıkı şartıdır. Bu şu demektir: Birinci unsur olmaksıżn ikinci unsur düşūnülmemek gerekir, yani toplum kavramının kurucu unsuru, mantıken harici bir kuralla belirlenmiş olmaktadır. Açıkcazsı, ilk unsur toplum kavranmının kalıbı, formu veya biçimi, ikinci unsur maddesi, muhtevasıdır. Hukuk , burada, ikinci unsurla degil, birinci unsurfa ilgilidir, yani biçim unsuru alanı- 
temele kavuşturulmuştur ${ }^{26}$. Ancak, çıkışı bu olmakla birlikte, hukuki formalizm, günümüzde, yenikantçılıkla bağımlı veya ondan bağımsız olarak hukuk, ceza hukuku biliminin, ve hiç olmazsa normatif teori açısından mümkün olan hukuk, ceza hukuku biliminin ortak malıdıı ${ }^{27}$. Hukuki formalizmi tüm ayrmtılarıyla incelemek, kuşkusuz konumuzun dıșında kalmaktadır. Burada, bizi ilgilendiren, hukuk biliminin, iddia edildiği üzere, hukuki formalizmde "formel bir bilim" olmakla zorunlu olup olmadığıdır. Bu hususun belirlenebilmesi için de, burada, hukuki formalizmden ne anlaşıldığının, başka bir deyimle hukuki formalizmde hukukun ne olduğunun saptanması gerekmektedir.

a. Hukukî formalizmde hukuk düzeni bir üstyapı, kurumudur.

Hukuk, esas itibariyla beşerî bir davranış normundan başka bir şey değildir. Böyle olduğu için de, o, altmda zorunlu olarak tükenmeyen hayatın yürek atışları olan toplumsal ve beşeri olgulanı bir biçimi, açıkcası bir üstyapısıđır ${ }^{28}$. $O$ halde, bizatihi toplumsal hayat maddeyi, buna karşılık normlar, bu hayatın birer kalıplarını teşkil etmektedirler. Bu da, hukuk normlarının, muhtevalarından, yani içerdikleri toplumsal hayattan bağımsız olarak incelenebilmesi demektir: Incelemenin konusu, sadece toplumsal hayatın kalıplari olan normlardı2 ${ }^{29}$.

na aittir. Bu yolda düșünme. Stamler'in hukuku ekonomiden ayrımasına yardım etmiştir. Stamler'e göre ekonomi incelemesi veya ekonomi bilimi, asla hukuk incelemesi veya hukuk biliminden başımsız olarak mümkün dę̆ildir. Nitekim denmektedir ki, hukuki bir irade imkanınca mantıken şartlandırılmıs olmayan hiç bir ekonomik kavram veya doktrin mevcut degildir. Oysa, tersi, daima mümkün olmaktadis. O halde. toplum hayatına ve bu hayatin altndaki ekonomik hayata gidilmeksizin ve ondan bağımsız olarak hukuk araştırması yapmak her zaman mümkündür (Zikreden, Bobbio. Teoria della scienza, s. 140 vd. Stamler hakkında bkz. Del Vecchio, Presupposti, s. 9, 94, 96, 100, 109, 112, 304). Stamler yenikantçıðır. Hukukun ekonomiye, ekonominin hukuka indirgenmesi veya hukukun toplumsal gerçeklikten bağımsız kilınması yolundaki düşünceler, kuramsal bilginin değil, genellikle idolojik yaklaşumlarin bir ürünưdür. Öyleyse geçerlilikleri ūzerinede tartı̧smak, hukukcu iłe ilgili bir sorun değildir. Stamlerin dūşüncelerinde bizce önemli görülebilen husus, hukukun toplumsal hayatın bir kalıbı oldugu ve bu kalıbın toplum hayatın sartlandırdığ, fakat ondan sartlanmadił̆ düşüncesidir. Bu yoldaki bir düşüncenin sonțcu bizce su olmaktadır: Hukuk.bilimi deneysel bilimler karşısında formel bir bilimdir. çünki deneysel muhtevadan bağımsızdır. Oyleyse ekonomi bilimi karşısında, hukuk bilimi, araçsal nitelikte olmak gerekir. Ancak, hukukun bir araç bilim olup olmadı̋̆ı ileride tartişıldığmdan burada Stamlerin bir değerlendirmesine gitmeye gerek yoktur. Bkz. Del Vecchio, Presupposti, s. 7-122

27 Bobbio, Teoria della norma, $\mathrm{S}$.

2B Bobbio, Teoria della scienza, s. 142.

25 Rocco, II problema e il metodo s. 578; Grispigni, La dogmatica giuridica e il moderno indirirzo nella scienza criminale, Riv. di dir e proc. pen, 1920, s. 12 13-; Toroslu, Cürümlerin, s. 6. 
Burada, form, 'biçim', 'kalıp' terimleriyle ifade edilmek istenen nedir?.

Felsefe dilinde birçok değişik anlama gelen 'form' terimi, hukuk bilimi ve felsefesinde, içerisine insanın belirii toplumsal davranışlarının ve hatta belirli doğal fiillerin girdiği belli bir yapıyı ifade etmektedir. Gerçekten, söz konusu davranışlar ve doğal fiiller, daha önce değil, fakat bu yapıya girmekle birlikte hukuki münasebetler ve fiiller niteliğini kazanmaktadırlar. O halde, "hukuk bir biçimdir" dendiğinde genellikle ifade edilmek istenen, hukuk normunun bazı fuil ve münasebetleri niteleyen veya nitelendiren bir yapı olduğudur. Bu anlamda, hiç bir fiil, hiç bir beşerî münasebet, varlığının doğal gereği olarak, başka bir deyimle "yaradılı̧ından" veya kendiliğinden hukukî değildir. Bunlar, ancak hukuk denen nitelieyici belli bir yaprya, bir kalıba girmekle birliktedir ki hukukilik sıfatına hak kazanırlar. Şu halde, hukukilik ve formel sıfatları, bütün bu hallerde aynı şeyi ifade etmektedirler, yani on anlamlidırlar ${ }^{30}$.

\section{b. Hukukun formel teorisi-hukukun normatif teorisi.}

Hukukun hukukî formalizm anlamında bir üst yapı olduğunu söylemek, hiç kuşkusuz hukuk deneyini sonunda normatif açıdan görmek, bał̧ka bir deyimle hukuku norm olarak düşünmektir. Görüldüğü üzere, bu açıdan hukukun formel teorisi, hukukun normatif teorisiyle aynı olmaktadır. Bu nedenle de "ekonomik, ahlâkî vs., bir münasebet kendisini hukukî olarak nitelendiren bir yapıya girdiği için hukukî bir mümünasebete dönüşür" önermesi yerine, "ekonomik, ahlâkî vs., bir münasebet bir hukuk normunca düzenlendiği için hukukî bir münasebete dönüşür" önermesi koyulabilmektedir ${ }^{3 !}$. Ancak zahiren esaslı

30 Grispigni, La dogmatica giuridica, s. 13; ID. Diritto penale, Milano, 1950, C.I, s. 10 vd.; Santroro. Scienza giuridica e realtà, s. 529; Toroslu, Cưrümlerin, s. 6.ve passim.

s) Bobbio, Teoria della scienza, s. 143 vd., 146; Kelsen, Lineamenti, s. 49-52; Degoişik fakat aynı, sonuç Carnelutti, Teoria generlare del reato, Padova, 1933, s. 23 vd. Hukukun formel teorisi, hukukî formalizm, bugün artık ideolojik kökeninden, ve metafizik izahından "bağtmsız olarak hukuk biliminin esaslı sorunlarının çözümünde kendisinden yararlanılan bir důşünce akımıdır, daha doğrusu bir metodtur. Örneğin, hukuk biliminin en çetin konularından biri hukuki münasebetir. Hukuki münasebet, süjelerarası bir münadebettir. Bu münasebet hukuk ve ceza hıkukunda normun sübjektifleştíriłmesi biçiminde orgataya çıkmaktadır. Acaba bu münasebet nedir? Hukuki münasebet, belli bir niteleme edindiğinden hukuki saylan etik, siyasî. ekonomik. açıkcassı toplumsa! muhtevalı süjelerarası bir münasebettir. $O$ halde, münasebette hukıkî olan şey münasebetin bizzat muhtevası değil, fakat münasebetin bu yolda nitelendirilmesi, yani biçimidir (Kelsen, Lineamenti. s. 81). İşte bu temel noktadan hareketle doktrinde süjeler arasındaki münasebet tipi, hukuken nitelendirilebildiginden, genelleştirilmek istenmiştir. Kimine göre, örneğin Stamler, hukukì nitelendirmenin konusu 
gibi görünen bu tür bir yer değişimi, hukukun ne ve nasıl bir bilim olduğu sorununu nihai bì çözüme ulaştıramamaktadır. Zira, sorun hukuki münasebet kavrammdan hukuk normu kavramına götürmek, sadece onu ait olduğu alana itmektir, ama çözümlemek değildir ${ }^{32}$. Hem hukukun normatif teorisinde hem de hukuki formalizmde hukukun ne ve nasıl bir bilim olduğu sorunu, hukuk normunun tanımının hukuk kavramı üzerine ortaya çıkan her sorunu tükettiği anlamında, hukuk normunun ne olduğunun bir belirlenmesi, yani bir tanımı sorunudur ${ }^{33}$. Bu ifade ile hukukun tek mümkün anlayıșı hukukî formalizmdir denmek istenmemektedir. Aksine, denmek istenen şey, hukukun bir üstyapı olmasında normatif teoriyle özdeşlik gösteren hukuki formalizmin hukuku toplumsal gerçekliģin bir biçimi veya üstyapısı olarak almamazhı edememesinin, normatif teoii doğrultusundaki hukuk, ceza hukuku bilimini, bir kısım doktrinde ileri sürüldügü gibi, gerçekten formel bir bilim olmakla zorunlư kılıp kılmadığıđır²4.

olan her münasebet, münhasıran ekonomik bir münasebettir. $O$ halde, hukuk, toplumun biçimi, ekonomi, muhtevasıdır ve biçim muhtevayı belirlemektedir, bu yüzden biçim muhtevadan bağımsız olarak incelenebilir. Bu na karşılık, gene!likle Marksçılar da dahil olmak üzere, kimi, aỷn başlangıç noktasından hareketle hukuku veya hukukî münasebeti ekonomiye veya ekonomik münasebetlere indirgemektedir (örneğin, Croce, Il libro del prof. Stamler, In materialismo strico ed economia marxsistica, Bari, 1961, s. 105-119, ID. Filosofia, poesia, storia, Milano-Napoli, Ricardi Edirore, s. s. 596-625). Ancak, belirtmek gerekir ki, hukuk düzeninin toplumsal gerçeklikte bir biçim bir ùstyapı olduğtunu kanıtlamak için ne hukuku ekonomiye ne ekonomiyi hukuka indirgemeye gerek yoktur, Çünkủ her iki durumda da, hukukî münasebetin muhtevasındaki çoğulculuk bir yana, hukukun bir biçim olma nitelig̣i ortadan kalkmamaktadır. Ileri sürülen dūşünçeler, sonunda muhteva-biçim etkileşimi ile ilgili olụp, çözūmû, sorun bir hukuk sorunu olmadığından, konumuz dışında kalmaktadır. Oyleyse hukuki formalizm için önemli olan, hukukun ekonomiye indirgenmesi veya ekonominin hukukla bağımlt kılımnası değil, toplumdaki muhtemel bir çok münasebetterden, kökenleri itibarnyla neye indirgenirse indirgensin, hiç birinin doğal olarak veya kendilịğin den hukuki bir mūnasebet olmadığıdır. $O$ halde, hukukî münasebet denjlen münasesebetler, insanlar arasındaki cari diğer münasebetlerden, etik ekonomik münasebetlerden muhtevası neđeniyle değil, sadece biçimi nedeniylo ayrılmaktadır. Bu da şu demektir. Bir münasebet hem ekonomik hem de hukukî bir münasebet olabilir. Başka bir deyimle, bir münasebet, sadece ekonomik veya sadece etik bir münasebet olarak mevcutken saslece hukuki olan, yani fitraten hukuki olan bir mūnasebet mevcut değildir, Çünkü bir münasebet hukuki münasebetse, bu demektir ki biçiminden ötürü hukukî münasebettir (Bobbio, Teoria della scienza, s. 114-145). Hukuki formalizm açısından hukukun öteki sorunları hakkında da, örneḡin hukuka aykırtlık, hukukî fjiller, haksız. fiiller vb., aynı doğrultuda đüşünülebilmektedir. Ancak, amaçımı hukuki formalizmin ne olduğunu belirlemek olduğundan burada örnekleri çoğaltmaya gerek bulunmamaktadir. 
Demek ki, bu sorunun çözümü, formel bilimler' terimi ile bugün kastedilen şeyin ne olduğınun bilinmesine bağlı olmaktadır.

c. Formel bilimler ve hukuk, ceza hukuku bilimi

"Deneysel bilim" - "formel bilim" ayrımında, formel bilimler denince acaba ne anlaşılmak gerekmektedir. Bilindiłi üzere, deneysel bilimler genel alanı içresinsinde, deneysel bilimlere 'araçlık hizmeti gc̈ ren' matematik ve mantık gibi 'biçim bilimleri'de bulunmaktadır. Biçim bilimleri, yani matematik veya mantık, deneysel olarak gerçekleştirilebilecek olaylar, olgular ve fïllerle deģil, fakat münhasıran semboller ve onların teskiliyle ilgilidirler. $O$ halde formel bilimler dendiği zaman, deneyin muhtevasıyla ilgili olmayan, sadece deneyin içinde ifade edildiği dilsel-mantıki biçimle ilgili olan bilimler anlaşılmak gerekmektedir. Bu bilimler, deneysel dünya üzerine kurulan ifadelere sahip değillerdir; fakat deneysel dünya üzerine kurulan ifadelerin teşkili için sadece bazı sembollerin nasıl kullanılacağını göstermektedirler. O nedenle, formel bilimler denen bı bilimlerin önermelerinin temel karakteri 'analitik'liktir. Öyleyse, bu önermeler 'tautolojik' karakterdedirler. Buna karşılık deneysel dünya üzerine ifadelere sahip bilimlerin, yani deneysel bilimlerin önermelerinin temel karakteri 'sentetik'liktir. Bunun sonucu, bu önermeden 'tautolojik' karakterde değildirler. İşte önermeler arasındaki bu temel farktan hareketle denilebilir ki, semboller üzerine çalışan ve kendilèrini sadece 'analitik önermeler' ile ifade eden bilimler, kendilerini 'sentetik önermeler' ile ifade eden bilimler, yani deneysel bilimler karșısında, yaradılıșları itibarıyla veya kendiliklerinden bir amaçları olmadığından, deneysel bilimlerin teșkiline 'mantıki-dilsel' araçlar hazırlama anlamında araçsal bilimlerdirler. Başka bir deyimle, bu bilimler, fülller üzerine çalışan bilimlerin teşkilinde zorunlu 'operasyonları' güdüp kolaylaștırdıklarından, sentetik önermeler olușturulmasında tıpkı yardımeı bir sağlama, bir hesap mekanizmasıdırlar. Şu halde, bunlar, kendilerine özgü bir konuya sahip değildirler, yalnızca bilimin, yani araçsal olmayan her bilimin yegâne konusu "deneysel konunun" hazırlanmasına yarayan bir önermeler sistemini teşkil etmektedirler ${ }^{35}$.

$\mathrm{Bu}$ veriler karşısınđa acaba hukukun genel teorisinin ve hukuk biliminin durumu ne olmaktadır.

Gerçek şu ki, hukukun bir biçim, bir üstyapı olarak ele alınması, başka bir deyimüle hukukun normatif teorisiyle hukukun formel teorisinin, yani hukukî formalizmin bu bakımđan özdeşlik göstermesi,

35 Bobbio, Teoria della scienza, s. 148 
hukuk bilimini yukarıda anlatılan anlamda formel bir bilim olmakla zorunlu kılmamaktadır. Ç̈̈nkü hukuk biliminin, formel bilimlerden farklı olarak, kendisine de özgü olsa, bir konusu vardır ve bu konu gerçeklik üzerine teşkil edilen normatif önermeleridir, yani beşeri davranı̧ kurallarıdır. Bu da gösteriyor ki, hukuk bilimi, kendisine ait bir konuya sahiptir ve bu nedenle de tümden soyut bir bilim değildir. Bu bir yana, 'biçim-form' teriminin, önce de belirtildigi üzere, bir değil, bir çok anlamı bulunmaktadır. Bunun için de 'matematik-mantık formel bilimdir' demekle 'hukuk toplumun bir biçimi, bir üstyapıs1dır' demek, her halde aynı şey olmamak gerekir, çünkü her iki önermenin içerdiği şeylerin biri ötekinin özdeşi de gildir ${ }^{36}$. Mantık-matematikk, önèrmeleri, özel muhtevalarını hesaba katmaksızın sadece önermeler olarak alıp incelemektedir. Başka bir deyimle, matematik veya mantık, sözler veya sembollerin ifade ettikleri şeyden bağımsız olarak, münhasıran önermelerin, yani anlatımın 'teşkili ve değişimi operasyonunu' araştırmaktadır. O nedenle, gerek mantık, gerek matematik, sembolleri sadece semboller olarak degerlendirir ve münhasiran semboller üzerinde çalışır. Her ikisi için de önemli olan, sembollerce ifade edilen anlamlar değil, fakat münhasıran sembol olarak sembolleridir ${ }^{37}$. Halbuki hukuk bazı beşeri münasebetleri nitelendiren bir yapıdır. Başka bir deyimle, $o$, belirli bir deneme alanınon bir nitelemesidir. Öyleyse, nitelediği denemeyi, yani mubtevayı hesaba katmaksızın hukuku incelemek mümkün değildir. Bu durumda, mantığin veya matematiğin konusu önermeler, zorunlu olarak 'salt biçim önermeler' olurlarken, hukuk biliminin konusu önermeler, yani hukuk önermeleri veya hukuk normları belli bir muhtevanin 'normatif nitelemesi' olmaktadırlar ve o nedenle de, mantık veya matematiğin aksine, anlamlarından yoksun kılınmađıkça, muhtevalarından arındırılamamaktadırlar ${ }^{38}$.

Mantık, görüldüğïi üzere, mümkün her anlatımm geçerliliği şartlarının bir araştırması iken, hukuk, sadece ve sadece, deneye ait bazı fiil veya münasebetlerin bir "faraziyesi" olmaktadır, çünkü deneye ait bu münasebetler ancak bu faraziye ile birlikte özel bir nitelik kazanmaktadırlar. Gerçekten, türü ne olursa olsun, hiç bir önermenin 'mantıki bit niteliği' yoktur ama önermelerin' mantıki bir geçerliliği vardır. Halbiki, bunun tersine, bazı toplumsal işlemlerin hukukî bir niteliği bulunmaktadır. $\mathrm{O}$ halde, hukuk bir biçimdir denildiğinde ifade edilmek istenen husus, hukukun, sadece ve sadece bir nitelendirme (= qualificazione) olarak bir biçim olmasıdır. Buna karşılık bu terim

Bobbio, Teoria della scienza, s. 138.

\$7 Bobbio, Teoria della scienza, s. 151

se Bobbio, Teoria della scienza, s. 152 
mantığın kendine özgï nitelï̛̆ni göstermek jçin kullanıldığında bununla sadece muhłkemenin geçerliliği genel şartları ifade edilmek istonmektedir. Hukukî muhakeme denilen muhakeme de, kisaca hukuk mantığı da, hiç kuşkusuz buraya dahil olmaktadır. Görüldüğü üzere, burada sınırları kesinlikle belli iki farklı formalizm ortaya çımaktadtr: Bunlar hukuki formalizm ve manttki formalizmlerdir ${ }^{39}$.

Ancak, bu aysıma doktrinde gereken önem verilmemiş ve çok kez hukuk bilimiyle matematik veya mantık arasinda yararlı bir para. lelliğin kurulabileceği düşünülmüștür. Bu doğrultudaki düşünceler yeni değildir batta düşünce tarihinde her zaman ortaya çıkmış ve günümüze kadar da gelmiştir. Bugün bu görüş̧ler genellikle yenikantçı düşünürler tarafindan savunulmaktadı ${ }^{40}$. Burada, bizi ilgilendiren, ayrintılar değil, hukukla mantık arasında paralellik kurulabileseği düşüncesinin kökenleridir. Bu düşsünceler, kökenlerini genellikle 'akılcılık' akımında bulunmaktadır. Nitekim, söz konusu paralellik. hukukta eylemlerin bir tür mantığını görme eğiliminden çıkarılmak istenmiştir. Kimi bu esasa dayanarak, hukuku, 'manevi bilimlerin matematiğ' olarak nitelendirmektedir. Hatta, bu yoldaki kıyaslamayı daha da ileri görüren kimi düşünür, hukuk bilimini 'formel bir bilim' saymaktadır. Hukuk Önermeleri, bu düşünürlere göre, 'mümkünler ideal alemine dahil maternatik ilkeleri ve mantık kanunları' ile aynıdır ve bundan ötürü 'münhasiran hukuka ait bir hukuk metodu' mevcut değildir ${ }^{4}$. Hukuk biliminin, farklı açıdan da olsa, formel ve soyut bir bilim olduğu görüşü bugün de ileri sürülmektedir. Bu düşünceye göre, hukuk bilimi, 'tüm hukuk deneyinin bir geomertrisidir'. Denmektedir ki, salt hukukçu, istidlal eder, müşahade etmez; o sadece mantık yardımryla hukukun geometrisini kurar ${ }^{42}$.

$\mathrm{Bu}$ görüșler doktrinde eleştirilmiştir; halen de eleștirilmektedirler. Nitekim, hukukun formel ve soyut bir bilim olduğu fikrine karşıllk,

3n Bobbio, Teoria della scienza, s. 153.

- Bobbio, Teoria della scienza, s. 153. Ancak mantık hakkinda bkz. Copi, Introduzione, s. 13-16, 22; Baturhan-Grünberg, Modern mantık, s, 1 vd.; Hukuki formalizm ve mantık için bkz. Del Vecschjo, Presupoosti, s. 69-77, 83-106, 107-122.

* H. Cohen ve Schreier'e atfen zikreden, Bobbio, Teoria della scienza s. 154

12 Kelsen`e atfen zikreden, Antolisei, Per un indrizzo realistico s. 25; Battaglini, Principi di diritto penale, Milano, 1929, s. 7,; Grispigni, La dommatica giuridica, s. 10; Pozitif hukuk bilimi münhasıran hukuk metodu ile iş görür. Bı metod, tabiatının gereği olarak rasyonel mantıkłır. $O$ halde büyük ọ̈çüde analizden ve tümevarımdan yararlanır. bununla birlikte o esasen "istidlalî bir bilimdir" ve özellikle soyutlannalardan yararlanır (Grispigni, La dommatica giuridica, s. 11). Hukuk dogmatigi "formel" bilimdir (Grispigni, La dommatice giuridica, s. 12). Bu niteliklerinin bir gereği olarak da o, rasyonel geometri ve matematige yaklaşmaktadrr (Grispigni, la dommatica, giuridica s. 13). Toroslu, Cürümlerin, s. 5 ve passim. 
aşırı formalizm ve soyutçuluğun hukukun düşmanı olduğu söylemektedir $^{43}$. Öte yandan akılcılkk akımına dayandirılan formalizmin esasen siyasî bir düşüncenin hizmetinde olduğu ve bu nedenle de liberal bireyciliğin aşılmasıyla birlikte aşılmış olduğu iddia edilmiştir ${ }^{44}$. Her ne ise, bu genel düşünceleri bir yana bırakarak, sorunun çözümü için hukuk ile matematik veya mantık arasında bir paralellik kurulup kurulamayacağını araştırmaya çalışalım.

Hukuk ile matematik veya mantık arasinda bir paralellik, olsa olsa kaba bir kıyaslamadır. Hukukun mantık veya matematik olduğunu. söylemek başka şey, hukukta mantık veya matematik metodlarının uygulanabilecəğini söylemek başka şeydir. Hukuk biliminin metodu mantıksal metot'dur ve 'hukuk bilimi hukukun bir mantığıdır' demek, her halde bir icad sayılmamak gerekir, çünkü öteki bilimlerin metodlaları da acaba mantık değil midir ve aynı mantık içerisinde kalarak, örneğin fizik için dog̀anın, sosyoloji için toplumun mantığıdır demek acaba imkânsız mıdır. Görüldügü üzere, hukuk biljiminjn mantıktan yararlandığ esası ortaya konulmakla birlikte, hukukla mantık veya matematik arasındaki kıyaslama da bitmektedir. Hukuk bilimi, ne matematik ve ne de mantık bilimidir, ancak işlemlerinde matematik veya mantık düşüncesinden yararlanmaktadır. Başka bir deyimle, hukuk bilimi, kendine buyruk 'karakteristik' bir metod degildir, öteki bilimlerin yararlandığı ve saptadiğı metodlardan o da yararlanmaktadır. Hukuk ile matematik veya mantık arasındaki ilişki, öy!eyse sadece ondan yararlanmaktan ibarettir. Ustelik öteki bilimler de matematiksel metodu veya mantığı kullanmaktadırlar, ama hiç biri için bunlar mantık veya matematiktir denilmemektedir. Nitekim fizigin matematikle aynı şey olduğu söylenememektedir. Şu halde, sorunun çözümü kökenini burada değil, fakat deneysel-formel bilimler ayrummda bulmaktadır: Deneysel bilimler, bilindiği üzere, metod clarak matematik veya mantık dilini kullanmaktadırlar. Bu dili teşkil eden birlimler formel bilimlerdirler. İşte o nedenlerdir ki, hukuk biliminin matematik veya mantık olduğunu, yani diğer araştırma alanlarında kullanılabilecek bir dil olduğunu söylemek başka şeydir, buna karşllk hukuk biliminin matematik veya mantık diliyle kendisini ifade ettiğini söylemek gene başka şeydir ${ }^{45}$. Öyleyse, iki şeyi biribirine karıștırmamak gerekmektedir. Ama, yeri gelmişken belirtelim, bir dil olarak hukuk bilimi anlatımınin matematik veya mantıktan nasıl nerede ve hangi ölçüler içinde yararlanacağı sorunu, bu konunun sınırları dışında

Maggiore, Diritto penale, V.I, TP. s. 89.

\$4 Antolisei, Per un indrizzo realistico, s. 29; Treves, Il metodo teleologica, s. 547 vd.

4 Bobbio, Teoria della scienza, s. 154-155. 
kalmaktadır. Ancak, șu kadarını söyleyelim ki, Rocco'nun “teknik hukuku okulu" tüm eleștirilere rağmen bu sorunların çözümünde hâlâ büyük ölçüde geçerliliğini korumaktadtr ${ }^{46}$.

\section{d. Hukukun genel teorisi formel bir bilim midir?}

Hukukun genel teorisinin hukukun formel teorisi olduğu söylenmekle birlikte, hukukun ekonomik, toplumsal, vs. muhtevasindan bagimsiz normatif yapisinm bir bilgisi olan veya normun norm olarak değerlendirilmesi ve kurucu unsurlarının bir incelemesi sayllan hukukun genel teorisi, mantık veya matematiģin formel bir bilim olması anlamında formel bir bilim değildir. Evet, mantık veya matematiğin formel bir bilim olduğu için araçsal bir değere sahip bulunduğu nasıl söylenebiliyorsa, ayn şekilde hukukun genel teorisinin de, hukukun özel disiplinleri karșısında, birlikte hem formel, hem de ara̧̧sal bir değere sahip olduğu söylenebilmektedir. Zira, denmektedir ki, hukukun genel teorisinin sağladı̆̆ salt hukuk biçimlerinin teșkilinin, kendinden bir amacı yoktur. O nedenle hukukun genel teorisi, hukukun özel disiplinleri için sadece bir inșa şeması olarak iş görmektedir. Öte yandan hukukun özel disiplinleri, sürekli olarak hukukun genel teorisince teşkil edilmiş olan mədellere gitmek zorundadırlar, aksi halde araștırmalarında bir adım bile ilerlemek olanağına sahip olamazlar, çünkü bu bağlantı, tıpkı fizik bilimletiyle matematik ve mantık arasındaki bağıntı gibidir. Ancak, bú tür bir kıyaslama, ne kadar ince olursa olsun, kıyas şartlarının bulunmaması nedeniyle geçerli olmamak gerekir. Geçersizlik, arą̧salık teriminin, biri ötekinden farklı iki anlamda kullanılmış

ae Teknik hukuk oikuluna göre hukuk incelemesinin konusu münhasıran pozitif hukuktur (Rocco, Il problema e ilmetodo, passim). Hukuk araștırması üç evreden müteşekkildir: Şerh, sistem ve elştiri evreleri. Bu evreler arastarında bağımlılık göstermektedirler. O nedenle bir evre tamamlanmadan öteki evrelere geçilemez (Racco, II problema e il metodo, s. 562 vd). Șerh, ceza hukuku kurallarının bir yorumu safhasıdır. Bu safhada bütün yorum çeșitleri ve yorum vasıtaları, hatta bazı sınırlar altında klyas da kullanilmaktadır (Rocco, Il problema e il metodo, s. 563). Ancak, hukukçunun görevi bununla bitmemektedir; Yorumu sistem safhası izlemektedir. Rocco'nun dogmatik inceleme dedigi bu safhada pozitif hukukun, kendi sistematik koordinasyona ve mantı̆̆ içerisinde temel jlkeleri sergitenir ve anlatılır. Böylece hukuki münasebet ve müesseselerin teşkili sağlanmış otrnaktadır (Rocco, Il problema e il metodo, s. 164 vd). Görüldügü ũzere, hukukçunun bilimsel sistemini teşkil eden đil, normatif bir an!atım değil, fakat belli bir normatif anlatım üzerine teşkil olunan betimsel bir (descrittivo) bir anlatımdır. Son safha eleștiri safhasıdur. Ancak, bu safha bir değer yargısı vermek safhaș olduğundan, bakış açısıına göre degerlendirmenin sonuçları da değişebilmektedir (Rocco, Il problemea e il metodo, s. $572 \mathrm{vd}$ ). Teknik hukuk okulu hakktnda geniş bilgi ve eleştiriler için bkz. Dönmezer-Erman, Ceza Hukuku, GK., 1, 72-105 (104-5) ve Toroslu, Cürümlerin, s. 10-24). 
olmasından gelmektedir. Gerçekten, mantığın araçsallığı, mümkün olan her tip bilimsel çalışmada geçerliyken, hukukun genel teorisinin araçsallığı, yalnızca hukukun özel disiplinleri için geçerlidir. Bunun bir sonucu olarak, hukukun genel teorisi, madem ki bir bilimdir, mantıki bir yapıdan da uzak olmamak zorundadır. Bu durum da, hukukun genel teorisinin mantıktan bağımsız olarak var olduğunun bir kanıtı olmakta ve öteki bilimler mantıktan nasıl yararlanıyorlarsa aynı şekilde hukukun genel teorisinin de mantıktan yararlanması sonucunu doğurmaktadir ${ }^{47}$.

Diğer bir konu, mantığın araçsallığının, gelişimi için her tip bilimsel araştırmaya zorunlu araçlan sağlama anlamma gelmesidir. Gerçekten, bir araştırma, eğer araştırma olarak bir sonuca varmak istiyorsa, gelişimi şartları olan mantıkî biçimlere uymakla zorunludur. Halbuki hukukun genel teorisinin, hukukun özel disiplinleri karşisindaki araçsallığı, böyle bir araçsallık değildir. Hukukun genel teorisi, hukukun disiplinlerinin gelişimi şartlarını hazırlamamakta, fakat onlara bir 'niteleme şeması' açıkçası bazı 'niteleme șemaları' vermektedir. $O$ halde, hukukun genel teorisinin araçsallı̆̆ıla mantık veya matematiğin araçsallığı aynı şeyler değildir. Ne hukuk bilimi, ne de hukukun genel teorisi, mantık veya matematik anlamında, ne formel, ne de araçsal bir bilimdir ${ }^{48}$.

Durum bu olunca ortaya yeni bir sorun çımış olmaktadır. Hukukun genel teorisi de dahil olmak üzere genel olarak hukuk bilimi eğer formel bir bilim değilse, o halde nedir veya nasıl bir bilimdir?. Burada, karşımıza, iki ihtimal çıkmaktadır. Hukuk bilimi ya deneysel bir bilimdir veya deneysel bir bilim değildir. Bu sorunlar, çözümünü, hukuk, ceza hukuku normlarının deneye dayalı olup olmadığı sorununun çözümünde bulmaktadırlar.

\section{Hukuk, ceza hukuku normunun deneyselliği sorumu}

Deneysel bilimler 'müşahadeye', 'deneye' dayalı bilimlerdir. Başka bir deyimle, doğal yahut ruhsal denilen olguları araştıran ve araştırılan bu olguların farkları esasına göre biribirinden ayrılan bilimlere deneysel bilimler denmektedir. Deneysel bilimlerin niteliği, deneysel olarak gerçekleștirilebildiklerinden, deneysel olarak geçerli oldukları

* Bobbio, Teoria della scienza, s. 156-157.

- Bobbio, Teoria della scienzá, s. 157-158. Bkz. Levi. Natura e funzione della teoria generale del diritto, Scritti giuridici in onore della CEDAM nel cinquanternario sua fondazione, Padova, 1953, C.V.I., s. 23 vd. 
söylenebilen önermeler formülleştirebilmeleridir ${ }^{49}$. Hukuk bilimi, konusu ve bu konu üzerine inşa ettiği önermeleri itibariyle acaba bu anlam da deneysel midir? Başka bir deyimle, münhassıan hukukçuya ait olduğu söylenebilen bir hukuk olgusu gerçekte var midir. Cevap, her halde, olumsuz olacaktır.

Önce de belirtildiği üzere, toplumda, 'doğuştan' veya doğasının gereği olarak hukukî olan bir olgu mevcut değildir. Ne suç, ne de ceza dogaya ait kavramlar değillerdir. Bizim hukuk olgusu diye nitelenditdiğimiz olgu, gerçekte belli bir türden bir normca düzenlenmiş olmanın kendisine belli bir nitelik kazandırdığ toplumsal (ekonomik veya etik-siyasî) bir olgudan bașka bir șey değildir. Kaldı ki, hukuk önermeleri, yani hukuk normları, 'olması gereken alemine; ideal alemine' ait olduklarından, deneysel olarak da gerçekleştirilmemektedirler. Hatta, bu önermeler karşısmda, böyle bir sorun koymak da anlamsızdır, her hangi bir anlam ifade etmemektedir ${ }^{50}$. Gerçek bu olduğuna göre, acaba hukuk, ceza hukuku biliminin deneyselliğinden söz edilebilecek midir. Yok söz edilemeyecekse, hukuk bilimi manevi bilimler arasinda yer alan ve deneysel olmayan bazı disiplinlerden, örneğin 'doğmalar'dan ve 'özel felsefe'den nasıl ve ne yolda ayrilabilecektir'

a. Hukuk, ceza hukuku bilimi en son tahlilde deneye dayalıdır:

Doktrinde 'hukuk dogmatiği tarafmdan elde edilen bilginin 'felsefi' değil, 'amprik' olduğu söylenmiştir. Denmektedir ki 'hukuk dogmatiği' hatta çok genel kavramların tesbitine ulaştığı zaman dahi, hukuku 'amprik' bir olay olarak gözönüne almaktadır, çünkü bu tür kavramlar sadece kendisinden çıkarıldıkları hukuk düzenine dayanırlar ve yine o düzen yönünden bir deger ifade ederler, o halde, asli, felsefi, evrensel bir mahiyet arzetmemektedirler ${ }^{52}$ : Soruna aslında çok doğru

- Bobbio, Teoria della scienza, s. 159; farklı fakat aynı dogrultuda, Copi, Introduzione, s. 467-479. Ayrica bkz. Del Vecchio, Presupposti, s. 87-106; Preti, Praxis ed emprismo, Torino, 1957; Domenico, Emprismo e dogmatica nel diritto, In scritti giuridici in onore di F. Carnelutti. CEDAM, Padova, 1950. V.I., s. 249 vd. Bilimlerin teasnifiyle ilgili olmasa da deneysellik için bkz. Abadan Y., Hukuk felsefesi, s. 68 vd.

so Bobbio, Teoria della scienza, s. 159.

51 Bkz. Bobbio, Teoria della scienza, s. 78-99 ve 136 vd; Abaden Y., Hukuk felsefesi, s. 26-33; Caģl, Hukuk metodolojisi, s. 25 vd. ID. Hukuk ilmine giriş, tstanbul, 1971. s. $101-113$.

s2 Toroslu, Cürümierin, s. 4; Grispigni, Diritto penale italiano, Milano, 1952, V.I., s. 11 vd.; Rocco'ya göre yegane ceza hukuku, deney verisi olarak, yani pozitif ceza hukuku olarak mevcut olan hukuktur (Raocco, II problema e il metodo, s. 515-516). O halde, ceza hukuku biliminin deneyselligi bizzat bir deney verisi olan pozitif ceza hukukundan gelmektedir. O nedenle, hukuk bilimi tarafindan ejde edilen bilginin, 
bir teşhis koyan bu görüş, sanıyorliz ki bu konuda nihai bir çözüm sağlayabilecek önemli bir noktayı karanlıkta bırakmaktadırlar. Bu nokta, hukuk bilgisinin üzerine inşa edildiği hukuk düzenini teşkil eden önermelerin, deneysel sayılıp sayllamayacaklan hususudur. Gerçekten; bu ayrıntı dokrttinde çok zaman önemsenmemiş, bunun bir sonucu olarak da, hukuku bir üstyapı olarak idrak eden doktrinlerden bir kısmı hukuk araștırmalarında mantık metodlarına giderken asalt soyutçuluğa gitmekten büyük ölçüde kendisini kurtaramamış, sonunda 'hukukçu müşahade etmez, istidlal eder ve sadece mantık yardımiyla hukukun geometrisini kurar' demek zonunda kalmıștir ${ }^{33}$. Bu doğrultuda düşünmenin doğal sonucu, hukuk ve ceza hukuku bilimini, istenmese de, formel bir bilim saymadır ${ }^{s 4}$ : Hukuku formel ve soyut bir bilim sayan bu tür görüşler, hukukun genel teorisi bakımından bir ölçüde geçerli saylsalar da, hukukun özel disiplinleri bakımtndan hukuk bilimini formel bir bilime indirgediklerinden her halde geçerli sayllmazlar. $\mathrm{O}$ halde, hukuk bilimini formel bir bilime indirgemeden, onu dogmalar ve özel felsefelerden ayırmak için deneyselliği acaba nasıl ve hangi açıdan ele almak gerekir. Bu konuyu aydınlatmada tek çkar yol, olsa olsa, hukukçunun faaliyetinin ne üzerine oldugunu ve ne olduğunu saptamaktır.

Hukukçunun faaliyeti, sadece normatif önermeler üzerinedir. Normatif önermeler üzerine olan bu faaliyet, henüz bir müessese, bir sistem faaliyeti clmadan önce, bir yorum faaliyeti olarak ortaya çımak-

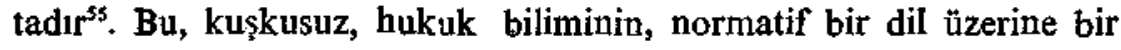
dil olmasının bir sonucudur. Gerçekten, hukukçunun başta gelen faaliyeti, hukuken geçerli normlar olarak kendisine verilen hukuk normlarının anlamlarının bilinmesi faaliyetinden ibarettir. Bir önermenin anlamının bilinmesi demek, semboller veya sözlerle, sembollerce veya sözlerce ifađ̉e edilen șey arasındaki uyumun saptanması demektir. $O$ halde, bir önermenin anlamının bilinmesi için, hukukçunun, sadece

sadece çlkarlldıkları hukuk düzenine bakılarak deneysel olduğunu söylemek yerine bizzat pozitif hukukun deneysel olduğunu söylemek ve hukuk biliminin deney• selliğini deneysel olan pozitif hukuka dayandırmak bize çok daha geçerli görünmektedir. (Krș. Torozslu. Cürümlerin, s. 4). Bu ayrintı, küçŭk olde olsa, oyle santyoruz ki, hukuk biliminin kullandığı metodun gereğj olarak, soyut ve formel bir bilim sayılıp sayılamayacağı konusunda önem taşımaktadır.

* Battaglini, Principi, s. 7 vd, ; Toroslu, Cūrŭmlerin, s. 5; Grispigni, La dommatica giuridica, s. 11, 13 ve ilgili dipnotlar. Bu doğrultuđaki düşüncelerin eleştirisi ç̧in bkz. Antolisei, Per un indrizzo realistico, s. $29 \mathrm{vd}$.

14 Grispigni, La dommatica girridica, s. 12 passim ve ilgili dipnotlar; Toroslu, Cürùmlerin, s. 6; Santoro, Scienza giuridica e realtà, s. 529.

st Rocco, Il problema e il metodo, s. 563 vd.; Grispigni, La dommatica giuridica, s. 14; Toroslu, Gürumlerin, s. 13 vd.; Bobbio, Teoria della sciènza, s. 168, 175 vd. 
ișaretler üzerinde değil, aynı zamanda işaretlerde ifade edilen şeyler üzerinde de çalışması ve daima ișaretten ifade edilen şeye giden 'atıfsal bir faaliyeti' gerçekleştirmesi gerekmektedir. Bu faaliyet, hukukta "hukuk yorumu" denen faaliyettir. Hukuk yorumu, öyleyse hukuk normlarının bir anlamını bilme faaliyetinden ibarettir. Normun bu anlamını bilmek, ancak normu teșkil eden ifadenin gerisinde ifade edi-. len bulunup çıkarıldığında mümkün olabilmektedir ${ }^{56}$. Hukukçu, ancak bu işlemlerden sonradır ki, genel kavramlara varır, genel kavramlar arasındaki bağıntıyı kurar ve onların tam ve tutarlı bir sistemini teşkil eder. İște bu sistem, hakukçunun bilimsel sistemidir, yani belli bir normatif anlatım (dil) üzerine inșa edilmiş bir bașka dildir. Bu dilin anlatım araçları, artık normatif önermeler değil, ama tasviti (betimsel) önermelerdir ${ }^{57}$.

Yorum faaliyetinde, normun, amacindan (scopo, ratio) soyutlanarak salt bir biçim veya basit bir üstyapt olarak idrakinin mümkün olup olmadığı konusu, doktrindeki sekişmelerin üzerinde yoğunlaștığı önemli noktalardan biridir. Bu cümleden olarak denmektedir $\mathrm{ki}$, ceza hukukçusu sadece bir fiilin ne zaman suç teşkil ettiģini ve gerçekleşmesi halinde hangi hukuki sonuçları gerektirdiğini düzenleyen kanun hükümlerini ait oldukları toplumsal gerçekliği gc̈zönüne almadan inčler diyen ${ }^{58}$ mantıki- formalist anlayış, kısmen tutarsızdır ${ }^{59}$, çünkü hukuk, hiç bir zaman salt bir biçim, basit bir üstyapı değildir. O nedenle, hukuk yorumu ve buna bağlı olarak hukuk incelemesi, sadece hukuk normlarının mantıkî-formel işlemleriyle sınırlandırılmamak gerekir ${ }^{60}$. Sonra, normun amacl, norma yabancı bir unsur da değildir ${ }^{61}$, çünkü hukuk düzeni, mahiyetinin bir gereği olarak 'teleolojik' bir yapidır ${ }^{62}$. O nedenle, normun amacının ortaya çıkarılması, normun kapsam ve anlamının doğru biçimde bilinmesinde zorunlu olduğundan, yorum faaliyetinden sayilmak icap eder. Ancak "teleolojik metodun" da vurgulandığı bu noktada kalmak soruna kuramsal bir çözüm getirmemekteđir. Bunun için de son bir adımı daha atmak gerekmektedir. Eğer gerçekten hukuk normunun muhtevasını idrak için 'amaç' zo-

\footnotetext{
Bobbio, Teoria della scienza s. 176

"Bobbio, Teoria della scienza s. 20I ; Rocco, Il problemea e ilmetodo, s. 564; Petrocelli principi, s. $12 \mathrm{vd}$.

so Örneğin, FGrispigni, Corso di diritto penale, 1932, s. 19; Toroslu, Cürümierin," s. 24; Petrocelli, Principi, s. 12 vd. 15 vd.

so Antolisei, Per un indrizzo realistico, s. 32: Düşünür, bu doktrinin, kısmen değil, tümden reddedilmesi gerektiǧnini söylemektedir.

6 Antolisei, Per un indrizzo realistico, s. 32.

- Antolisei, Per un indrizzo realistico, s. vd., 32.

62 Rocco, L'oggetto, S. 443 vd.
} 
runluysa, bir kere amacın idrak edilebilmesi için de bizzat normca kurallaștırılan toplumsal fiilin gözönüne alınması zorunlu olmaktadır ${ }^{63}$. Bu konu ile ilgili olarak denmektedir ki, hukuk bir biçimdir, ama bir muhtevayı zorunlu kılan bir biçimdir; hukuk kuraldır, öyleyse kurallaştırılmış bir fiil olmadıkça mevcut olmamak gerekir, hukuk toplumsal münasebetler disiplinidir, öyleyse toplumsal münasebetlerle bağımlı kılınmadıkça idrak de edilemez: Hukụk, beşeri münasebetleri yaratmaz, onları toplumsal gerçeklikte bulundukları biçimde ele alır ve yine toplumsal olan amaçlara ulaşmak amacıyla onları kurallaștıIII $^{64}$. Bu demektir ki, normda kurallașan toplumsal fiil veya münasebet, amaca eşit olarak, normun kurucu bir ögesi olmáktadır. Bu kurucu öge, 'kanunun maksadının veya amacın' ortaya çıkarılmasında zorunlu olduğu için, kanun hükmünün ve uygulama sınırlarının bilinmesinde, hukuk dışı bir unsur sayilmamalıdı, çünkü o, bizzatihi hukukun içinde maddeleştiłgi bir özdür. Bundan ötürü, normca kurallaştırılan fiili gözönüne alınmaksızın hukuku sadece 'hukuken' yani 'formel biçimde inceleme' iddiasında olan herkes kısır bir döngüye düşmek ve sonunda norm tarafından düzenlenen füllle fiili düzenleyen normu birbirine karış-. tırmak zorunda kalır ${ }^{65}$.

Durum bu olunca, yorum faaliyetinde ifade edenden ifade edilene gitme zorunluğunun esası ne olmaktadur. Sorưr, çözümünü, normatif önerlmelerin gerçeklikle olan bağıntısında bulư. Norlatif önermeler, bilindiği üzere, 'var olmalı' karakterde önermeler değildirler. Ama, bu, onların gerçeklikle bağıntılı olmadıkları anlamına da gelmemektedir. Normatif önermeler, mümkünün ifadesi olan farazi davranı̧larm önermeleridirler. Ancak, bu önermelerin muhtevi oldukları mümkünlük veya farazilik kavrami, salt akılđan değil, tam tersine bizzat toplumsal gerçeklikten çıkarılmaktadır. O neđenle, konusu normatif önermeler üzerine uğraşmak olan hukukçu, önermelerin kendisinden sadece varlık nedenini değil üstelik müteșekkil olduğu fikir veya kavramları da çıkardığı toplumsal gerçeklige gitmeksizin, o önermeler in taşıdığı anlamı bilme olanağına sahip olmamak gerekir. Hukukçunun işi, asına bakılırsa, normun kendisinden kaynadığı ve düzenlemeyi

Antolisei, Per un indrizzo realistico, \$. 32.

* Rocco Alfredo, Politica e diritto nelle vecchie e nuove concezioni dello stato, Nuova antologia, 1931, s. 364.

4 Antolisei, Per un indrizzo realistico, s. 33; Rocco, Sulla sistematica della parte generale del diritto penale, Annali, dir. proc, pen. 1935, s. 973 vd. Antolisei'de göre hukukçu, hukuk araştırmasında, mantığın kảı kuralları içerisinde sıkışıp kalmamalı, tersine mantığ hayatın zorunlululuklarına uydurmalıdır. Hukukun realis akımını formalist akımından ayrıran ölçŭ de budur (Antolisei, Per un indrizzo realistico, s. 34). 
amaçladığı toplumsal gerçekliğin irdelenmesinden başka bir şey değildir. Garçakten, fiilì gerçeklik üzerine hiç bir yargı verilmezse de, normatif önermelerin belirlediği gerçek şeylerin bilgisi ne kadar iyi derinleştirilebilirse, normatif önermelerin anlamlarının bilinmesi de o kadar iyi sağlanmış olmaktadı ${ }^{66}$. O nedenle, kanunun idraki veya bilinmesinde, kanunđan çıkarılan malzemeden bașkasına gerek olmadığı, o halde hukuk biliminin deneye ihtiyą̧ göstermeyeceği, çünkü onun hemen hemen kanunun salt bir istidlali olduğu görüşü, her halde geçeıli değildir, çünkü belli bir davranışı düzenleyen bir normun anlamını bilmek için hukukçu, matematik veya mantıkçıdan farklı, tarihçi veya sosyologdan hiç de farkı olmayarak, gerçek davranışı müşahade eder ve müşahade sonunda elde ettiği bilgiden yorum görevini yapmak için yorumda zorunlu olan öğeleri çıkarir ${ }^{67}$. Bu zorunluluk, bugün hemen herkeş̧e, değişik bir biçimd z de olsa, kabul edilmiş bulunmaktadir ${ }^{6 s}$.

Bobbio, Teoria della scienza, s. 176.

* Bobbio, Teoria della scienza, s. 178.

e* Ornegin. Grispigni, Dir. Pen., C.I, s. 10, 22; Toroslu, Cürümlerin, s. 18 vd. ve özellikle 24 . Hukuk biliminin aslında deneye ihtiyaç göstermediği, çünkü hemen hemen kanunun bir tür salt biçimsel istidlali" olđư̆gu görüşü, ceza hukukunda, genellikle, bir kısım teknik hukuk metodu taraflarınca savunulmuştur. Belki o nedenle olacak, teknik hukuk metodu, doktrinde, hemen hemen mantıki formalizmle eș tutulmuş ve bunun sonucu, söz konusu metoda, çok zaman geçerli olmayan eleştiriler yönetilmiştir. Bu durum, her halde. kimi teknik hukuk okulu taraftarlanının, hukuk bilimine iliskin bazı sorunların çözümünde, mantıkt-formel bir araştırma çizgisine girmis olma* larından ileri gelmektedir. O nedenle, hukuk biliminde tek geçerli araş̧ırma metodunun teknik hukuk metodu olduğunu söylemek başka şey, araştırmada mantıki-formel bir araştırma çizgisine girmek başka şeydir. Esasen teknik hukukçu olmak, mutlaka hukukun mantıkî-formel anlayışını benimsemeyi gerektırmez. Teknik hukukçu olup da mantıki formalis olmamak mümkün olmak gerekir. Çünkü, iki şeyden biri, ötekinin zorunlu sonucu değjldir. Kaldı ki, hukuk bilimi alanında bir araç olarak mantık veya matematiğin uygulanmast, ne ölçüde ve nasıl uygulanacă̌̆ı başka şey, hukukla matematik veya mantık arasinda bir benzerlik kurmak ve sonunda hukuk bilimini manttkî-formel bir bilime indirgemek başka şeydir. Burada da kanttlarnaya çalıştığmız üzere, hukukçunun faaliyeti, matematikçi veya mantıkçının faaliyetinden çok, tarihçi veya sosyoloğun faaliyetine benzermektedir. $O$ halde, sorunun çözümü, hukukun kun deneyselligi sorunu üzerinde dügümlenmektedir. Eł̌ nacaksa, deneysel değil araçsal olan mantık veya matematikle hukuk arasında bir benzerlik kurmaya da imkân olmamak gerekir. Teknik hukuk metodunda hukuk önermeleri, yani pozitif hukuk dedigimiz hukuk, yegane deney verisi hukuktur (Rocco, Il problema e il metodo, s. $516 \mathrm{vd)}$. Hukuk bilimi deneye dayanan bu önermelerin bir bilgjsi olduğundan, öyleyse mantık veya matematiğe benzetilemez. Hukukun bir üstyapı olarak idraki bu esası ihlal etmemektedir, Çünkü hukuk bir çok kez de belirtildiği gibi, amaçtan yoksun bir yapı deģildir, Başka bir deyimle teleolojik' bir yapıdır Bu her hukuk önermesinin bir muntevasının bulunması demektir. Bu nitelik de, hukuku, mantık veya matematikle eş tutmaya engeldir. Ancak, bu sonuc, hukukun bir nitelendirici biçim olarak incelenemeyecełi anlamına alınmamak gerekir. Zira, aksini anlama, ya "hukukun genel teorisi" diye bjr disiplin tanımamaya, ya da mantıki 
Önemli olan, gerçeğin şu veya bu biçimde ifade edilmiş olması değil, hukuk normlarınca "ipotezleştirilen" farazi davranışların bilinmesinde gerçek davranıșlarm müşahadesinin esas olduğunun kabul edilmiş olmasıdır. Bu ifadeyle, fiiller üzerine yargı olmalarına ragmen, normatif önermelerin bilinebilmelerinin ancak fïllere gidilmekle mümkün olacag̀ı hususu kastedilmektedir. Kuşkusuz normatif önermeler, birer gerçeklik yargıları, varolmalı yargılar değillerdir, ancak bu yönleri, onların deney üzerine kurulmuş olmalarına engel teșkil etmez, çünkü normatif önermelere varolmalı bir anlam izafesinin inkârı, aynı zamanda onların deneysel temellerinin inkârı demek değildir. Normatiflik ve deneysellik terimleri, birlikte bulunmayan veya biribirlerini çelen terimler değildirler. O nedenle, denilmektedir ki, hukuk kuralları veya hukuk önermeleti, hem normatiftirler, hem de sonunda bir beşeri deneyden gelmektedirler ${ }^{69}$.

Hepsi bir yana, deneye gitmek, sadece bir hükmün anlamm bilmede değil, o hükmün öngörülṃeyen benzer hallere genişletilmesinde veya teşmilinde de zorunludur ${ }^{70}$. Bu işleme, hukukta, genişletici yorum veya daha doğru olarak 'kıyas' denilmektedir" ${ }^{71}$ Hukukta kıyas mümkündür. Ceza hukuku sistemimizde, üzerinde tartışmalar olmakla birlikte kıyas tümden reddedilmiş değildir. Bu hukuk dalında kıyasın sının 'suçlar ve cezaların kanuniliği' ilkesidir. Öyleyse bu sınır đışında kalan pek geniş bir alan, örneğin mazeret sebepleri, cezaya etkili bazı sebepler,

formalizmle hukuki formalizmi eş tutmaya götürûr. Biz hukuki formalizmle mantıki formalizmin aynı şeyler olmadı̄̆nı söylemiştik. Sonra, hukuk biliminin mantıkî-formel bir bilim olduğunu söyleyenler bile, yukarıda örnek olarak zikredildi, deģişik bir yaklaşımla da olsa, hukukđa deneyin zorunlulưğunu kabul etmiş durumdadurlar: Hukukçu, ortaya koyduğu inşaaların keyfi bir takım şemalar olmaktan çııı üstyapısını teşkil ettikleri beşeri ve toplumsal muhtevayı gerçekten yansıtabilmeleri için elini toplumsal titresimlerin nabż üzerinde tutmak zorundadır (Grispigni, Dir. Pen., C. 1. s. 22). Bu arada, belirtmek gerekir ki, bazı hukukçular, farkl1 bir teori ile ortaya cılkmıs görūnseler de, kısmen de olsa. teknik hukuk okulunun benimsemiş görünmektedirler (Örneğin, Antolisei, Per un indrizzo realistico, s. 14-17; Meggiore, Diritto penale, V.I, T.P., s. 89 vd). Bu göstermektedir ki, ceza hukukunda teknik hukuk metodu verileri doğrultusunda dưşünmek, mutlaka mantıki formalist düşünceyi benimsemeyi zorunlu kıImamaktadır. Kaldı ki Dönmezer-Erman'da, bazı kayıtlarla, ceza hukuku biliminde geçerli metodun teknik hukuk metodu olduğunu söylemektedir (Dönmezer-Erman, Ceza Hukuku, GK., s. 1, s. 104-105) O halde, elestirilmesi gereken husus, hukukun bünyesinden gelen hukuk formalizm değil, hukuk bilimini sonunda deneysellikten çıkarı mantıki-formel bir bilime indirgeme eğilimleridir.

* Bobbio, Teoria della scienza, s. 177.

70 Bobbio, Teoria della scienza, s. 178.

"Bobbio, Analogia nella logica del diritto, Torino, 1935; ID. Analogia Novissiom digesto, 1957, C.I. s. 601 vd.; Giannini, L'analogia giuridica, "Jius', 1941; Boscarelli, L'Analogía giuridica, Riv. Trim. di dir. e proc. civ, 1954. 
vs., yasak kapsamı dışında kalmıș sayılmaktadır ${ }^{72}$. Bunun bir sonucudur ki, yasak dışındaki anlanlara münhasızr olmak üzere hukuk sistemimizin genel yapısının bir gereği olarak (MK. Md. 1), ceza hukukunda klyas mümkün olmaktadit ${ }^{73}$. Sonra, unutmamak getekir suçlar ve cezaların kanuniliği ilkesi ile yasaklanan şey, kanun hükmünün gerçek kapsamını ortaya çıkarmaya hizmet eden kıyas veya kıyas suretiyle yorum değil, tam tersine bir ceza normuna, yani tecrim edici bir norma kıyas suretiyle yapılan ilâyedir ${ }^{74}$. Bu göstermektedir ki, hukuk dalları arasında özel bir yeri olan ceza hukuku, bu konuda, kısıtlı da olsa, deneye yabanct değildir.

Göı üldüğ̈ü üzere, bizzat davranışları değil, ama davranış kurallarını incelemeyi konu edinen hukuk ve ceza hukuku bilimi, bu gereği yerine getirebilmek için, doğrudan olmasa bile, belli bir deneye dayanmak, başka bir deyimle, az da olsa 'müşahadeye' yabancı olmamak zorundadır. Acaba, bu durum, ta baştan beri tartışılan hukukun ve ceza hukukunun deneyselliğini kanttlamaya yeterli miđir? Sorunun çözümü, tabii ki, deneysel bilim terimiyle neyin kastedildiğine bağlıdır. Deneysel bilim terimiyle kastedilen eğer bilgisinin nihai kaynağı olarak deneyi tanımaksa ${ }^{75}$, hukuk ve ceza hukuku bilimi, bu anlamda doğrudan değil, fakat 'en son tahlilde' deneysel saylmak gerekir. çünkü hukuk biliminin konusu, yani davranıș kuralları, kesinlikle deneyin dışında bir yere konulamamakta, yani "a priori" olarak ideal ilkelerden çıkarılamamakta, aksine tarih, sosyoloji, siyasî ekonomi vb. bilimlerin konusunu teșkil eden beșeri alemin öteki şeylerinden farkh olmayarak araş-

"Erem, Ceza hukuku, GH. c. I, s. 98; ID. Gerekçeli Türk Ceza Kanunu, Ankara, 1948, 5 vd.; Alacakaptan, Ingiliz ceza hukukunda sụ̧ ve cezaların kanuniligi prensibi, Ankara, 1958, s. 26; Antolisei, Manuale, di diritto penale PG, Milano, 1963, s. 68 vd. Manzini, Trattato, V.1. s. 307; Rocco, L'Ogetto, s. 546-550. Krş. Carnelutti, Teoria generale del reato, s. 144; Petrocelli, Principi s. 152 vd.

1s Ceza hukukunda kıyas hakkında Ör., bkż. Vasasili,. Limiti del divieto di analogia in materia penale. Milano, 1942; ID. Analogia nel diritto penale. Novissimo digesto, C.1., s. 607 vd.; Boscarelli, Analogia e interpretazione estensiva nel diritto penale, Palermo, 1955; Bettiol, Aplicazione analogica della legge penale, Riv. It. di dir. e proc. pen., 1931 ; Delitala, Analogia in "bonam partem", Riv. It. di dir. e proc. pen., 1936 Florian, Analogia come fonte di norme penali, Riv. Dir. Penit., 1936; ID. Analogia penale dei giuristi e analogia penale degli antropologi criminalisti, Sc. Pos., 1936; Demirel, Ceza hukukunda ktyaslama yasağının mahiyeti, AD. 1950, No: 7; Ragıp. Ceza huku kunda kıyas ve tefsir, -AD. 1939. No. 1.

7 Cass. 20. Aprile, 1925, Giuest, pen., 1952 s. 644: Ceza hukukunda kıyas yasağı ile yasaklanan sey, bir ceza normuna kiyas suretiyle yaptlan eklentidir, o halde, kanunun gerçek kapsamını ortaya çıłkarmaya hizmet eden kıyasî yorum (interpretazione ana- . logica) yasaklanmıs değildir.

7 Bobbio, Teoria della scienza, s. 178; Başka bir konuyla ilgili ama aynı doğrultuda Copi, Introduzione, s. 475 vd. 
tırıcının içine nüfuzuna imkân veren toplumun bazı gerçek devinimleri üzerine, bazı gerçek münasebetler ve bazı gerçek davranıșlar üzerine oturmaktadır ${ }^{76}$. Varılan bu sonuç, az önce tartışması yapılan hukuk bibiliminin salt mantıki araçlarla ișleyen formel-mantıkî bir bilim olduğu görüşü karşısında ${ }^{77}$ özel bir önem taşımaktadır. Hukuk biliminin formel - mantıkî anlayışı, hukukçunun faaliyetinin bir fizikçinin veya sosyoloğun faaliyetinden çok, bir matematikçinin faaliyetine benzediğini varsaymaktadır. Hukuk bilimini dogmalaștıran ve onu belli bir 'tutuculuk' ve kemikleşme içine sokan bu anlayış, karşıtı olarak doğan doktrinler tarafindan şiddetle eleștirilmiştir ${ }^{78}$. Konumuzla sinirlı olarak, biz, şunu söylemekle yetineceğiz: Hukuk bilimi madem nihai tahlilde deneyseldir ve bu deneysellik onun yorumsallik karakterinin bir sonucudur, o halde hukukçunun faaliyeti mantıkçı veya matematikçinin faaliyetine değil, aksine fizikçinin, sosyoloğun faaliyetine benzemektedir. Ancak, bu benzerliğe dayanilarak, hukuk nasıl matematik veyà mantiktır denilemiyorsa, sosyolojidir de denjlememektedir, çünkü bu ikj farklı disiplinin deneysellik açısından benzerlik göstermesi, hiç bir zaman varlıklarına vücut veren konularının da benzerlik göstermesi sonucunu doğurmamaktadır.

Bu açklamadan sonra, en bașta sorulan soru tekrar sorulabilir. Hukuk bilimi deneysel bir bilim midir, yok değilse dogmalar ve felsefeden nasıl ayı lacaktır? Hukuk bilimi, açıklandığı üzere, doğrudản degil, ama en son tahlilde deneyseldir. Bu temel niteliğinden ötürü normatif önermelerin bir bilgisi olarak ortaya çıkan hukuk ve ceza hukuku bilimi, manevi bilimles tasnifi içerisinde yer alan fakat deneysel sayılmayan đüşünce sistemlerinden, yani dogmalar ve felsefeden ayrılmaktadır ${ }^{79}$. Öyleyse, hukuk, ne bir dogma, ne đe özel felsefedir, sadece ve sadece

34 Bobbio, Teoria della scienza, s. 178; Rocco, Il problema e il metodo, s. 504 ve passim.

3 Grispigni, La dommatica giuridica, s. 13: Ote yandan hukuk dogmatigi, soyut bir bilimdir, çünkü hukuk, bir soyut normlar bütünūdür ve o toplumsal hayatın soyut bir inşaasını ortaya koymaktadır, o halde bu inşaayı könu edinen bir bilim soyut bir bilim olmaktan başka bir şey olamaz. Gerçekten, hukukçu, bir soyutlama işlemiyle, karmaşı ve çokbiç̧imli (multiforme) tezahür eden beşeri münasebetlerde, etik, siyasî ve ekonomik görünümlerden hukukî görūnümü ayrımak zorundadır ve sadece bu unsur kendisine özgü araştırmasının konusu olmak gerekir. Işte bu soyutlama işlemi nedeniyle hukuk bilimi (dogmatiği) rasyonel geometri ve matematiğe yaklaştırimaktadır.

s Bu konu ile ilgili olarak "hukukun sosyolojik teorileri" yantnda "teleolojik metod" menfaatler giurisprudansı kavramı ve "realist hukuk akımını" zikretmek mümkūndür. Bkz. Bobbio, Teoria della scienza, s. 182-190 ve 179; Treves, Il metodo teleologico, makalenin tümü; Antolisei, Per un indrizzo realistico, makale tümú ile; Bettiol, Dirritto penale, PG, Palermo 1945 (1962), Cap. II

* Bobbio, Teoria della scienza, 136, 175, 178. 
bilgisinin nihai kaynağı olarak deneyi tanıyan bir disiplindir. En son tahlilde deneye dayalı olmak, araștırmayı, zoı unlu olarak deneyselliğin sınıIı sorununa götürmektedir.

\section{b. Hukuk, Ceza Hukuku biliminde deneyseiliğin sınırı.}

Ancak, hemen belirtmek gerekir ki, bir hukuk normunun anlamını bilmede deneye gidilebilmesi demek, önce de đendiği üzere, araştırmada hukuk normunun kendisinden vazgeçmek ve araștırmanın amaçlarında münhasıran toplumsal deneyden yararlanmak demek değildir ${ }^{80}$. Nitekim, Rocco, daha bu çağın başında, yegane ceza hukukunun, 'tek gerçəklik verisi olarak mevcut olan pozitif cæza hukuku' olduğunu kanitlayarak, bir yandan cəza hukukunun 'tabii hukuka" ${ }^{\text {81 }}$ öte yandan 'genel sosyolojinin uygulamalı bir bölümüne' veya 'suç sosyolojisine ${ }^{32}$ indirgenmesine engel olmuştur. Roccocu düşüncede hukuk araş-

Bobbio, Teoria della scienza, s. j79.

- Tabiî hukuk anlayışında egenen egilim, pozitî hukuk dışında bir ceza hukuku yaratma eğilimidir. Amaçlanan şey, devletin pozitif kanunlarında jfadesini bulan hukukun dişında ve ondan farklı bir ceza hukuku yaratmaktır. Böylece, kökenleri "ide" ve akıl kanunlarında veya tabii kanunlarda yahut beșerî viçanın tezahürü veya jlahì bir kaynakta aranan evrensel, deģişmeyen, mutlak karakterde bir ceza hukuku yaratıl mak istenmiştir. Bu doğrultudaki düşunncenin temel niteliği, hukuk bilimini, beşeri deneyfn sunurları ötesine itmesinde kendini göstermektedir. Hukukçunun inceleme konusu pozitif hukukla tabit hukuk arasindaki uyumun incelenmesi ve bu uyumu sağlaytcı kanunların bulunup çıkarılmasıdır (Rocco, Il probleme e il metodo, s. 500504). Tabii hukuk hakkenda Ör. bkz. Kelsen, Lineamenti, s. 77 vd., 61 vd.; Bobbio, Teoria della norma. s. 49 vd.; Abadan. Y, Hukuk felsefesi, s. 135 vd.; Ross, Diritto e giustizia, Böl., XI-XII; Hart, Il concetto di diritto. Böl. IX. Ceza hukuku alanında genellikle 'klåsik ceza hukuku okılu' adıyla bilinen akım, tabii hukuk akımının ceza hukuku alanındaki bir yansıtısıdır. Beccaria ile başlayan bu akımın en büyük temsilcileri, örneğin, Carrara, Romagnosi, Rossi, Carmignani, Pessina olmuştur (Bkz. Rocco, Il problema e il metodo, s. 501 vd ve dipnot $4 \mathrm{vd}$.; okutlara göre Italyan ceza hukukçularını bir tasnifi için bkz. Maggiore, Diritto penale, CV.I PG., TP., s. 91).

82 Rocco, Il problema e il metodo, s. 513 ve dipnot 31, 517 ve dipnot 32. Ceza hukuku alantnda "pozitivist okul" ceza hukuku bilimini tabiri caizse genel sosyolojinin uygulamalı bir bölümüne veya suç sosyolojisine indirgemiştir. $O$ nedenle pozitivist olculla "hukuki positivizmi" birbiriyle karıștırmamak gerekir. Hukuki pozitivizm, yegano gerçektik verisi olarak pozitif hukuku alan bir hukuk anlayışıdır ve tabîi hukuk doktrinlerinin karşıtı olarak alınmalıdtr. Öyleyse, pozitif hukukun bilimi olan ceza hukuku bilimi. pozitivist okulca belirlenen muhtelif suçların tehliketilik durumlarına ait teknik bilgilerin tümü anlamındaki "ceza ilmi" değildir (Battaglini, Principi, s. 7 vd). Kaldı ki, hukuki pozitivizmle pozitivist okulun bukuk biliminin konusu ve metodu olarak saptadikları hususlar da birbirinden farklıdur. O nedenle, pozitivist okulun sergilediği ceza hukuku bilimi, pozitif hukukun bir teorisi değil, fakat suç ve ceza ile ilgili olarak bir suç "sosyolojidisir" (Bkz. Rocco, Il problema e il metodo, s. 513 vd 517 deki 31 ve 32 numaralı dipnotlar; Grispigni, La dommatica giruridica, s. 3 vd). Nitekim, Ferri, bundan böyle "suçlu bilimi (= la scienza criminale) nihai amacinda ve 
turmasınin pozitif hukukun bilinmesine inhisar ettirilmekle yapılmak istenen, sadece ve sadece ceza hukuku bilimi araştırmalarının doğrudan konusunun kendine özzü hukuk bilimi olma r.iteliğine uygun olaıak, münhasıran ceza hukukunun, yani deneysel veri olarak, başka bir deyimle pozitif ceza hukuku olarak var olabilen yegane ceza hukukunun incelenmesiyle ve uygun biçimde bunun araçlarıyla sınıtlandırılmasıdır ${ }^{83}$. Bu sınırlamanın doğal sonucu, cəza hukuku biliminin suç ve cezayı, sadece ama sadece hukuki açıdan, hukuk normunun düzenlediği fiiller, yani biri sebep öteki hukuki sonuç olan hukuki fiiller olarak ele alıpincelemesidir. $\mathrm{O}$, bu fiillerin, birinin toplumsal ve bireysel bir fiil olarak, yani toplumsal ve dogal, organik, psikolojik açıdan, ötekinin toplumsal fiil olarak ele alınıp incelennmesi işini başka bilimlere, açıkcası asıl konularını teşkil ettikleri antropoloji ve suç sosyolojisine ${ }^{84}$ bırakır. Bu terkle güdülen amaç, kimilerinin ileri sürdügüunün aksine, ceza hukuku araștırmalarını kalıplaștırma, onları tamamen teorik bir soyutlamaya indiıgeme veya konularını teşkil eden fiilleri yeşerdikleıi doğal ve toplumsal gerçaklikten soyutlama değil, aksine ceza - hukuku bili* minin konusu ve sınırlarını tesbittir. Bu konu ve sınurları ise suç denen beşerî ve toplumsal, ceza denen siyasî ve toplumsal fiillerin sadece hukuki tanzmininin, bașka bir deyimle hukuken organize toplum için bir tehlike ortaya koyabilen ve dolayl olarak haksızlik ve zararlar meydana getirmeye elverișli isnat edilebilir beșeri fiilleri yasaklayan hukuk normlarının, o halde hak ve vecibenin, yani normların varlığından ötürü normlardan doğan ceza hukuku münasebetinin incelenmesi olmaktadır ${ }^{85}$.

Açıktır ki, bu doğrultudaki bir düşüncede, hukuk normunun bilinmesinde deneye gitme zorunluğu inkâr edilmemekte, aksine hukuk kavramına bir sınır getirilmek suretiyle hukuk düzenini bir normlar sistemi bütünü olarak idrak eden hukukun normatif teorisine sadık kalınmak istenmektedir. Hukukun normatif teorisi, hukuk araştırmasının içinde cereyan ettiği ortam ola1ak ve hukukçunun hukukçu-

sonuçlarında bir hukuk disiplini olarak kalmış olmasına rağmon, esasları ve inceleme araçlarında sosyolojinin bir dalına dönüşmek zorundadır demektedir (Ferri, Sociologia criminale, 4. ediz., 1900, s. 919). Düşūnüre göre, teknik anlamda "suçlu hukuku" (- Il diritto criminale) suç sosyolojisinin hukuk bölümū olmak zorundadır (Ferri, Sociologia, s. 12). Grispigni, Introduzione alla sociologia criminale, Torino, 1928; Guadagno, Oggetto e limiti delle sociologia criminale, Arch. pen., 1962; Dönmezer, Kriminoloji, 4. basi. Istanbul, 1971,

os Rocco, Il problema e il metodo, s. 514-516.

- Suc sosyolojisi, antropoloji ve psikoloji ile ilgili olarak bkz. Rocco, Il problema e il metodo, s. 517 ve dipnot 32; Di Tullio, Trattato di antropologia criminale, Roma, 1945; ID. Principi di criminologia clinica e paschiatria forense, Roma, 1959. 
dan başka şey olma, örneğin sosyolog, ahlakçı, filozof olma tehlikesine düşmeksizin térkedemeyeceği ortam olarak, sadece ve sadece 'hukuk normunu', daha doğrusu 'belli bir hukuk normlan bütününü', açıkcası' hukuk düzenini' gözönüne almaktadır ${ }^{\text {66 }}$. Hukuk düzeni, deney veya gerçeklik verisi olarak mevcut olabilen yegane düzen olarak, pozitif hukuk düzenidii ${ }^{87}$. Deney verisi olmak, beșeri varllklarca konulmuş olmaktır: Pozitif hukuk, beşeri varlıklarca konulmuş geçerli bir normlar sistemi bütünüdür. Hukuk biliminin konusu yalnızca bu konulmuş hukuku incelemektir. "Hukuk tatbikatı" denen faaliyet, sadece bu hukukun tatbikidir ${ }^{88}$.

Deney verisi olarak mevcut yegane hukuk normu, belli bir normatif düzende, açıkcası belli bir hukuk düzeninde geçerliliği (= validità) bulunan normdur. Gerçekten, bir davranıs kuralı, ait olduğu sistem içinde eğer geçerliyse hukuk normu olmaktadır. Öyleyse, bir davranış kuralının hukuk kuralı olarak varolması, o davranış kuralının hukuken geçerli olmasıyla eş anlamlıdır ${ }^{89}$. Norm, burada, belli bir açıdan dȩ̧erlenđirilmektedir. Bundan başka, norm, adillik (= giustizia) ve etkinlik (= effiçcacia) açılarından da ele alınıp değerlendirilebilir. Norma izafe edilen bu üç bakış açııı, bir bütünün farklı yönlerini ifade etmekle birlikte, biribirlerinden tamamen bağımsızdır ${ }^{\infty}$. Fakat hukuk de-

- Boddio, Teoria della scienza, s. 179 vd.

"Bobbio, Teoria della scienza, s. 198; Rocco, Il problema e il metodo, passim; Antolilisei, Manınale, PG., s. 14; Toroslu, Cürūmlerin, s. 10. Bu konuda en geniş bilgi için bkz. Bobbio, Giusnaturalismo e positivismo giuridico, Milano, 1972; Scarpelli, cos'e. il positivismo giuridico, Vernona, 1965.

6a Scarpelli, Cos'è il positivismo, s. 105 ve passim; geniş bilgi için, Binder, La fondazione della filosofia del dititto, Trad. di. A. giolitti, EINAUDI, 1945, cap. IV.

s Bobbio. Teoria della scienza, s. 197 vd.; Kelsen, Lineamenti, s. 103. 180 vd.; Scarpelli, Cos'e s. 59 vd.; Ross, Diritto e giustizia, Böl. II; Hart, Il concetto di diritto, s. 118 vd. Doktrinde, genellikle, geçerlitik yerine "yüruriük" terimini kullanmaktadır: "Münhasıran olmasa bile ceza hukuku biliminin başta gelen görevi ve fonksiyonu, yūrürlükteki ve pozitif ceza hukukunun hukuki-teknik incelemesidir" (Rocco, It problema e i] metodo, s. 521); Antolisei, Manuale, PG., s. 14 vd.; Bettiol, Dititto penale, s. 54; Petrocelli. Principi, s. 16 vd.; Dönmezer-Erman, Ceza hukuku, GK. C.1, s. 10 10 vd.; Toroslu, Cürŭmlerin, s. 10. Teziç, Tũrkiyede 1961 anayasasına göre kanun kavramı, İstanbul, 1972; Yazar kanuntarının muteberliģi ile yürürlügünü biribirlelerini takip eden işlemler olmaları bakımından biribirinden ayırmıştır (KIs. II ve Kas. III).

at Bobbio, Teoria della norma, s. 35-43: Normun adilligi sorunu, kisaca, belli bir hukuk sisteminin esinlendiği nihaî değeri, o sisteme ait norm veya normların karşılayıp karşılamadığı sorunudur. Bu da, sonunda ideal alemle gerçek alem arasındaki bir uyum sorunu olmaktadır. Oyleyse, bu açıdan adalet veya normun adilliǧi. gerçek olanla ideal olan arasındaki mutabakatta ifadesini bulmaktadır. İşte bu nedenle, hukukta adalet sorunu, bir normun adil olup olmaması sorunu, başka bir deyimle hukuk düzeninin aditligi sorunu, hukukun bir "deontoloji" sorunudur (Bobbio, Teoria della 
neyinin farklı yönlerini ifade eden bu üç bağımsız kavram, her nedènse doktrinde ya biribiriyle karıştırılmış veya biri ötekine indirgenmiştir. Bunum sonucu olarak da hukuk normunun, daha. genel olarak hukuk araştırmasının aslî konusunun ne olduğu sorunu, uzun bir süre kesin bir sonuca ulaştırılamamıştır ${ }^{\text {sl }}$. Hukukun normatif teorisiyle öteki teorileri arasındaki ihtilâf da esasen bu noktada yogunnlașmaktadır. Sorun, özerk bir disiplin olma sıfatını zedelemeden hukuk biliminin esas konusunu bulma sorunu olduğuna göre, sorunu çözmeye elverișli ölçütün, her halde hukukun kendi yapısı içinde aranması gerekmektedir. Hukukun bizzat kendisinden çıkarlabilecek ölçüt, doktrinde de kabul edildiği ăzere, ne davranış kuralının adilliği, ne de et-

norma, s. 36; Del Vecchio, Hukuk felsefeesi, s. 15 vd). Hukukun, daha dogrusu hukuk dūzeni veya hukak normunun etkinliği sorunu, normun muhatabı olan kimsenin, norma uyup uymadığt veya normun ihlali halinde normu koyan otoritenin zorlaytct araçlarla ihlali önleyip önlemediģi sorunudur. Oyleyse, bir normun adil olması baska ફ̧ey, etkin olması başka șeydir. Bu iki unsur biribiriyle bağımlı değillerdir: Bir norm adil sayıldığ halde etkin olmayabilir, etkin oldugu halde adil sayılmayabilir. Normun etkinliẓ̌ araştırması, zorunlu olarak, tarihi-sosyolojik bir araştırmadır. $O$ halde, normun etkinliži sorunu hukukun bir "fenomenoloji" sorunudur (Bobbio, Teoria della norma, s. 38 vd.; Del Vechihio, Hukuk felsefesi, s. 15 vd). Normun geçerlilitīi sorunu, ne bir deontolojí, ne de fenomenoloji sorunudur. $O$, sadece, ama sadece normun hukuk normu olarak var olması, yani mevcudiyeti sorunudur. Bu sorun, biribiriyle bağımlı ủç ayrı sorunu isermektedir: 1) Normu koyan otoritenin hukuk normu koymada meșru bir otorite olup olmadığ1, yani norm koymada kanuni iktidara sahip olup olmadığg; 2) Normun başka bir hukuk normu tarafindan sarih veya ztmni ilga suretiyle kaldırılıp kaldırılmadığ; 3) Normun ait olduğu sistemi teşkil eden diğer normlarla çelişip geçelişmediği. Iş̧te bu üç ayrı faaliyeti içeren normun geçerliligi sorunu, hukuk doktrininde, hukukun "ontoloji" sorunu olmaktadır (Bobbio, Teoria della norma, s. 36-38; Del Vecchio, Hukuk felsefesi, s. 15 vd). bkz. Ross, Diritto e giustizia, Böl. 11, XII; Hart, Il concetto di diritto. Böl. VI, VIII, IX; Kelsen. Lineamenti, Böl, II, V. Hukuk normuna bakış açıstyla ilgili olarak yapılan bu tür bit is bölümü, asiında, ceza hukukçucuna, hiç olmazsa teknik hukuk okulu doğrultusundaki ceza hukukçusuna, yabancı dełildir. Zira, teknik hukuk okulu messuou hukuk incelemesinde, hukuku hukukla ve hukukun araçlarıyla sıntılamayı isterken, dolay̧ı da olsa, söylemek istediģi, bu ayrımın saglanabilntesidir. Gerçekten, bu husus sağlanabildiğj takctirdedir ki ancak, hukukçu için, faaliyetlerinin ñzerinde toplanabileceği, müstakil bir araştırma alariı doğmaktadır. Aksi halde, hukukçu, daima kendisinden başkası olmakla, yani bir sosyolog, bir filozof veya bir ahtakçı olmakla karșı karşıya kalacaktır. Bu da, her hajde, hukuk biliminin sonu olmaktadır (Rocco, Il problema e il metodo, passim, ama özellikle s. 506, 518, 572 vd.; Grispigni, La dommatica giurica, passim).

- Bir normu değerlendirmede kullaılan bu ūç temel kriter biri digerinden farklı ve aralarında bağımsiz. Oç tür sorunlar dizisine vûcut vermektedir. $\mathbf{O}$ anlamda $\mathrm{ki}$, normun adilliği ne normun geçertiliği ne de etkinliği, normun geçerliliği ne adillix̧i ne de etkinliği ve normun etkintiği ne adilliģ̧ ne de geçerliliği ile baư̆ımltdır. Buradan ortaya çlkan sonuçlar şunlardtr: 1) Bir norm, hukuk normu olarak geçerli olmayabilir, fakat adil olabilir. Normun bizatihi adil olmast, aynı zamanda, onun hukuken gegerli 
olması demek değildir. 2) Bir norm adil olmadığı halde hukuken geçerli olabilit. Olanla olması gereken bağintısı hep meycut olduğuna göte, hiç bir hukuk düzeni, "mükemmel", nihai" evrensel" saylmamak gerekir. Unutmamak gerekir ki, "adalet fikri" ile "hukuk gerçeği" arasında, etik-siyasî ideolojiler veya siyasî rejimlerle bağımlı olarak, daima bir mesafe mevcut olmuştur. Nitekim, bir marksc1 için özel mülkiyeti koruyan hukuk sistem]eri nasıl adil deģilse, aynı şekilde, özel mülkiyeti esas sayan bir kimse için, özel mülkiyeti korumayan hukuk düzenleri adil degiildir. 3) Bir norm etkin olmayabilir, fakat, geçerli olabilir: Örnek vermeye gerek yok, hukuk sistemimiz. de bu tür norm azımsanmayacak kadar çoktur. En belirginlerinden biri, örneğin, mülga "men'i srafat kanunu" olnuştur. 4). Bir norm geçerli olmadığı halde etkin olabilit. Örneğin iyi davranış kuraliarı. $O$ halde münhasıran bir norma uyulmus olma, o normu strf bu nedenle gecerli kilmamaktadir. 5). Bir norm etkin degildir, fakat adil sayılmaktadır: Gerçi etkin norm, genellikle adil normdur, fakat, adil sayıldıkları halde etkin olmayan normların varlığı da inkâr edilmemek gerekir. 6) Bir norm adil sayılmasına rağmen etkin olabilmektedir, çünkü bir normun evrensel olarak uygulanması, onun mutlaka adil olduğgnun kanıtı değildir. Görüldüğü üzere normatif deney veya daha özel olarak hukuk deneyi için deişik birer bakış açısı olan bu üç terim, aralarında bağımsız oldukları için, biribirileriyle karıștııılmamak ve bjrini diggeri yerine koymamak gerekir, Çünkü bu terimlerden hiç biri bir öteki đeğildir (Hepsi hakkinda bkz. Bobbio, Teoria della norma, s. 39-43).

Ancak, bu üç farkh terim doktrinde hep biribiriyle karıştırılmı̧ ve çolk zaman biri diğerine indirgenerek hukuk ve hukuk biliminin ne olduğu açıklanmaya çalı̧̧ııışır. Bu karıștırmantn bir sonucu olarak, hukukun biribirinden farklı, üç anlayış ortaya çımıştır: 1) Geçerlitiği adilliğe indirgeyen teoriler: Bu teorilere göre, bir norm eğer adil ise geçerlidir. Burada, adalet unsuru geçerljlik unsurunun belirleyici şartı olmaktadır. Bu teorilerin "tipik" tarihi örneği, hukukun "tabii hukuk" anlayışlarıdır (Bobbio, Teoria della norma, s. 48, 49-54). 2) Adilliǧi geçertliliǧe indirgeyen teoriler: Bu teoriye göre, geçerli olan norm, aynı zamanda adildir. Burada adalet unsuru geçerlilik unsuru ile bağımlı kılımnıştır. Normun adil olup olmadığı diye bir sorun yoktur, çünkü hukuken geçerli norm zaten adil normđur. Bu teorilerin tipjk tarihi örneği, tabii hukuk doktrinlerinin karşıtı olan "adaletin kanuncu" anlayışları, yani dar anlamda hukuki pozitivizmleridir (Bobbio, Teoria della norma, s. 48, 54-60). 3) Geçerliliğ etkinliǧe indirgeyen teoriler: Bu anlayısa göre gerçek hukuk, bir anayasa, bir kanun veya bir kanunlar mecmuasinda yer alan veya bunlarla ifadesini bulan hukuk değildir. Gerçek hukuku, insanların her gũnkü münasebetlerinde bilfiil uyguladıkları hukuktur: Bu düşunce akımı, geçerliilģi, sonunda et'kinlikle bağımlı kılmaktadir. Geçerli norm, sadece etkin olan normdur ve etkin olan norm adildir. Bu teorilerin tịik tarihi örneģi, Amerikan hukuk doktrinindeki "realist akın" ve bu akımın Kara Avrupasındaki uzantısı "hukukun sosyolojik teorileri'dir (Bobbio, Teoria della norma, s. 48, 60-70).

Aslında, bu üg grup teori, hukuk deneyinin esaslı unsurlarından birini diǧerine indirgeme hatasından ötürü sakattırlar. Ama bu üç farklı bakıß̧ açısı, tek bir bütünün ực ayrı yönünü ifade etmektedir. Bu bütün, hukuk deneyidir. Adillik, etkinlik ve geçerlilik, bu bütünün varlığında, zorunlu unsurlardurlar. $O$ nedenle, karmaş̧k hukuk deneyini, zorunju unsurlardan sadece birine indirgeyerek açıklamaya imkân yoktur. (Bobbio, Teoria della norma, s. 47, 49), Çünkü toplumlarda hukuk deneyi ile gerçekleştirilmek istenen Şey, toplumu ve toplưmda insan hayatını en mükemmel biçimde organize etmekten başka bir şey değildir. Böyle bir organizasyon da, ancak, organizasyonun adilligi, etkenliģi ve geçerliligi ile sağlanabilir (Bobbio, Teoria della norma, s. 47). Öysleyse, zorunlu kilınan ayrum ile hukuk deneyinin temel görünümleri ihmal 
kinliğidir, davranış kuralının sistem içinde geçerliliğidir ${ }^{92}$. Gerçekten, bir norma hukukilik sıfatını bahşeden öge, ne o normun adilliği, ne de de etkinliğidir, ama geçerliliğidir. Hukukilik sıfatı, demek ki, geçerlikle

edilmemekte, aksine bunların biribirine karıștırılmasının hukuk deneyinin idraki yönünden zararlı olduğu kanıtlanmaya çalışılmaktađır. Bu durum karşısında, bu görünümlerden her birinin bir başka araştırmanın konusu olduğunu söylemek başka şeydir bu görünümlerin teşkil ettiği bütünũ tantmlamak için görünnümlerden birini digerine indirgemek bir bașka seydir.

'2 Scarpelli, Cos'e' s. 53-89; Hart, il concatto del diritto, s. 68-70, 105-108, 120-122; Kelsen, Lineamenti, s. 52 vd.; 103 vd.; 180 vd.; Bobbio, Teoria della norma, s. 35-39; ID. Teoria della scienza, s. 195-198. Hukuk düzeni eğer bir nomrlar sistemi bütünü ise bu sistem igerisinde kalarak sistemi teskil eden birimlerin degerlendirilmesinde. yani onların birer hukuk normu olarak var olduklarinı saptamada yegane geçerli ölçǜt geçertilik öłçütüdūr. (Scarpelli, Cos' e' s. 65; Bobbio, Teoria della norma, s. 37). Bu ölçütler esas alınarak hukuk biliminin konusunu belli bir pozitif hukuk sisteminin incelenmesiyle sınırlandırmak, hukuk deneyinin çoğulcu karakterinin yitiritmesini zorunlu kılmamaktadir. Zira, değerlendirme ölçütleri esas alınarak yapılan bu ayırım, kesin, nihai, aralarında ilintisiz bir ayırım değjldir. Ostelik hukuk deneyinin ne olduğunu bilmek isteyen herkes, bu beșeri deneyin, gerçekleştirilecek adalet ideallerinin, bu idealleri sağlayacak normatif müesseselerden ve bu idealler ve mūesseler karșısındaki insanların "amel ve aksuamellerinden" mūteşekkil olduğunu göz önüne almak zorundadır (Bobbio, Teoria della norma, s. 47). Bir önceki dipnotta da belirtildiggi gibi, bunlar, nihayet bir bütünün üç ayrı görünümüdür. Ancak, bu gör.nümlerden esas olanı, hukuk deneyinin normatif görünūmüdür. Bu görünümü bilmeye imkân veren unsur, her halde gecertiliktir. Burada normatif her hangi bir yapının değgil, hukukun adilliği ve etkinliği söz konusu olmaktadur. Öyleyse önce neyin hukuk veya hukuk normu olduğu bilinmeđikçe, adillik ve etkinlik de söz konusu olmamak gerekir. Ote yandan siyasi bir tavırla hukuki bir tavrı biribirine karıștırmamak gerekir. Adil ve etkin hukuk normu koymak başka bir şeydir, hukuk normunun adilliği ve

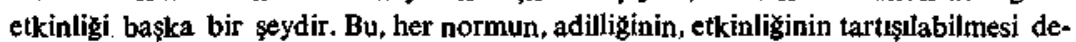
mektir. Ancak, bu hukuk normunun adilliği, etkinliği söz konusu olduğunda, normun önce bir hukuk normu olarak var olması gerekmekteđir. Görüldügüü üzere, sorun, bir alanlar "izolasyonu" sorunu değil, bir öncelik sortralık sorunudur. Nitekim, daha bu çằı başında Rocco, soruna parmak basmış, hukuk incelemesini ūç safhaya bölmüștür. Son safha, Rocco'da hukuk düzeninin bir eleştirisi safhasıdır. Bu safhada inceleme konusu yapılan hususlar, baska hususlar yanında, hukuk normunun veya hukuk sisteminin adilliği ve etkinliği soruntarıdır (Rocco, Il problemea e il metodo, s. 572 vd). Burada her hangi bir yanlıs anlamayı önlemek için bir noktaya da değinmek gerekmektedir: Hukuk normunun geçerliligi ile hukuk sisteminin geçerliliği = meşruiyeti konusu biribirinden farklı konulardır. Bir normun hukuk normu olarak var olması, tüm hukuk sistemini teşkil eden normların temel normla bağımımlı̆ı̆ı anlaminda iken, yani temel ölçü hukukun kendi içinde iken, hukuk düzeninin geçerliliği, bizzzat temel normun geçerliligi anlamındadır. Bu da, hiç kuşku yok, hukuk düzeninin bir bütün olarak 'meşruluğgu' sorunudur. Meşruluk sorunu, sonunda, bir egemenlik' sorunudur. Egemenlik sorunu, çözümünü, itiraf etmek gerekir, hukuk düzeninin düzen olarak etkinlið̧i sorununda bulmaktadır $\mathrm{Bu}$ da, asilnda fiilî bir gerçeklikten başka bir şey değildir ve bu nitelił̌ nedeniyle hukuki pozitivizm dogrultusundaki Hukuk incelemesinin kapsamı đışında kalmaktadur (Błz. Scarpelli, Cos' e', s. 74-77; Bobbio, Sul princjpio di legittimità, Studi in memoria di A. Falchi, Milano, 1964; 
bağgntılıdır. O nedenle, hukuk bilkiminin konusunu teșkil eden norm, hakuk normu, belli bir hukuk sisteminde geçerli olan normdur ${ }^{93}$.

Normun belli bir hukuk sisteminde geçerli olması ne demektir. Normun geçerli olması, yalnız Kelsenci doktrinde değil, ama hukuku normatif açıdan görmek isteyen bütün doktrinlerde bir "temel norm"dan çıkarak belli bir hukuk sistemine doğrudan doğruya veya dolaylı olarak giren bir norm tarafından kurallaştırılmak olarak anlaşılmaktadır. Temel norm ${ }^{94}$, burada, normatif her sistemin "geçerliliği" ilkesidir. Hukuk sistemi deyimi ile kastedilen eğer temel normla farklı kademelenmelerde bağımlı bir normlar sistemiyse, bir norm, bir tasatruf veya muamelenin hukukî varlık kazanması veya gecerli olması, o normun, tasarruf veya muamelenin ancak bir hukuk düzenine, yani bir noımlar

A. Passarin D'Entre 'ves, La dottrina dello stato, Torino, 1962, Part. II, Cap. X; Piovani, ll significato del principoi di effettività, Milano, 1953; Kelsen, Lineamenti, s. 101 vd., 103 vd.; Ross, Diritto e giustizia, s. 34 vd.).

99 Perassi, Introduzione, s. 32: Hukuk normu, belli bir hukuk dūzeninde yürürlükte olan norm anlamina gelmektedir.

94 Hukuk düzeni mademki bir normlar sistemi bütünüdür, o halde sistem olmayı să̆glayan bir başlangıç noktası itibar edilmek gerekmektedir. Hukuk sisteminde bu başlanğç noktası 'temel norm'dur. Temel norm hakkındaki düşüncelerìn dökümünün yapılıp eleştirilmesi konusumuz dışında kalır. Bizim için önemli olan, temel nlrom hakkıtndaki dūşūnceler dešil, bu terimin 'konvesiyonel' oluşudur. Bir bașlangıç noktası itibar edilmediģi takdirde madem ki hukuk dūzenini bir normlar sistemi bütünũ olarak açıkJamak mümkün değildir öyleyse temel normun da 'konvansiyonel' bir başlangıç noktası olarak alınması gerekmektedir. Aksi takdirde bir hukuk düzenininden söz etmek ve onun bilgisi olan hukuk bilimini varlığını kabul etmek mümkün olmaz, Hukukun salt 'rasyonel' bir sistem olmadığı, tersine içinde 'irrasyonel' unsurları taşıdığı yolundaki görüșler (örneğin. Antolisei, Per un indrizzo realistico, s. 17 vd), hukukun bir tür matematik veya mantık sayılmasina engeldir, ancak hukukun normatif bir sistem sayılmasına engel olmamak gerekir. Zira, hukuku bir tür mantık veya matematik saymak başka \$̧ey, pozitif hukuku bir normlar sistemi bŭtünü olarak görmek başka şeydir. Bu, hukukun içinde bazı 'irrasyonel' unsurların olmasının, hukukun bir sistem sayilmasina engel olmamast demektir. Buradan hareketle diyebiliriz ki, hukuk düzeni eğer bir normlar sistemi bütünü ise, o halde bu būtünün bir başlangṭ̣ noktası vardır ve bu nokta 'konvensiyonel'dir. Hukuk bilimi bilim olma vasfint yitirmeden ve hukuk içinde kalarak bulunabilecek tek temel esas, böylece temel norm varsayımı olmaktadır. $O$ nedenle, bir taraftan bir pozitif hukuk sistemi kabul edip ote yandan sistemi saglayan itibari bir başlangıç noktası kabul etmemek, her halde bir çelişkidir. Kaldı ki, temel norm üzerindeki tartışmalar, çok kez onun konvensiyonelliži üzerinđe dę̧il, mahiyeti ve yeri ùzerindedir, Bu hususun araştırılması kușkusuz. burada, konumuz dışında kalmaktadır. Konuyla ilgili olarak bkz. Ross, Diritto e giçustizia, s. 29-68; Hart, Il concetto di diritto, s. 95-145; Kelsen, Lineamenti, Böl. V; Scarpelli, $\operatorname{Cos}^{2}$ e', s. 71 vd.; Leoni, Oscurita ed incongruenza nella dottirina kelseniana del diritto., Riv. Int. Fil. del Dir., 1960, s. 165 vd.; Ago, Scienza, giuridica e diritto internazionale, Milano, 1950, s. 38 vd.; Conte G.A., Norma fondamentale, Novissimo Digesto, C. XI. s. 328 vd. 
sistemi bütününe ait olmasıyla mümkün olmaktadır. O nedenle, hukuk düzeni, yani geçerlilik ilkesi veya temel norm dișında, ne hukuki bir varlık, ne hukuk normu, ne de hukuk bulunmaktadırs. Bu, demektir ki hukukun normatif teorisinde mümkün olan yegane hukuk bilimi, konusu münhasıran hukuk olan hukuk bilimidir. Başka bir deyimle, yegâne hukuk bilimi, konusu yalnıza geçerli bir hukuk sistemine ait normatif önermeler olan hukuk bilimidir. Bu bilim, toplumdaki olgulardan, toplumdaki menfaat çatışmaları ve irade ihtilâflarından "kanunlar" çıkaran, bu kanunları açılayıp sistemleștiren ve işleyen bir bilim degildir, sadece 'pozitif hukukun biı teorisi'dir. Bunun için, pozitif hukukun bir teorisi dışında, ne bilimden, ne hukuktan ve dolayısiyle ne de bir hukuk biliminden söz edilebilir."

Bu sonuç kuşkusuz herkesçe kabul edilmiş değildir. Ceza hukuku bilimi alanınđa özel bir yeri olan 'pozitivist ceza hukuku akımı'ndan başka ${ }^{97}$, hukuk biliminin konusunun münhasıran pozitif hukuk

\$s Bobbio, Teoria della scienża, s. 196-197.

9. Bobbio, Teoria della scienza, s. 197.

- Bobbio, Teoria della scienza, s. 100-199. Ancak unutmamak gerekir ki, gerek pozitif hukukun teorisi olarak hukukun normatif teorisi, gerek bunun dayandığ hukuki pozitivizm ve gerekse hukuk biliminin metodu olarak ortaya çlkan 'teknik hukuk metodu, bugūn de üzerlerinde en yoğun tartışmaların yapıldı̆̆ bir konu olarak güncelliģini korumaktadur. Eleştiriler, genellikle tabii hukuk doktrini taraftarları, dinci dūşünürler ve kimi markş̧ı yazarlardan gelmektedir (Bkz. Scarpelli, Coc' e'. s. 135 vd). Hukukî pozitivizm ve buna bağlı olarak teknik hukuk metodu, bunlarca, nazizim ve faşizmin bir ürünü sayimıştır. Oysa, hukuki pozitivizm, nazizim ve faşizmin bir ŭrūnủ olarak değil, tam tersine tabiî hukuk anlayışının karşıtı dūşüncede bir evrim olarak ortaya çkmıştır. O nedenle bir rastlantı olarak ortaya çıkısı ile fașizimin ve nazizmin ayni döneme rastlamiş olması hukuki pozitivizmin bu rejimlerin bir ũrünü olduğunu kanıtlamaya yetmez, çünkä bir rejimin bir teknikten yararlanması başka şey, o tekniłgin bir rejimin doģal ürünü olmast başka şeydir. Kaldıki, hukuki pozitivizm bir ideolojiye temel olmak amacıyla deǧil; hukuktan ideolojileri kovmak iddiasıyla ortaya çlkmıştır (bkz. Kelsen, Lineamenti, s. 47, 59 vd. 65 ve passim). O halde, hukuki pozitivizm ve buna bağlı olarak teknik hukuk okulu 'Mus" solini Italyasında' vúcut bulmus olmasına rağmen, teknik hukuk okulunun 'totaliter ve otoriter bir doktrini telkin eylediģini sanmak hatalıđir' (Dönmezer-Erman, Ceza hukuku, GK. C. 1, s. 105). Hukuki pozitivizm, hukuk düsünce tarihinde, deneysel olmayan kảsşısında, deneyseli getirmiştir. Bu ise bir veridir, fakat bir değerkendirme değildir. Oysa, ideolojiler, degerlendirme alanlarıdırlar. Onedenle, bir ideoloji ile, bu ideoloji ne olursa olsun, bir verinin geçerliliği veya geçersizliğini kanıtlamak mantıken mümkūn olmamak gerekir. Hatta, hukuki pozitivizm bir ideoloji de saylsa, sonuç degişmemektedir, çünkü ideolojiler hakkında verilen yargt da sonunda bir değer yargısısıdır, yani kuramsal değil, ideolojik bir yargıdır. $\mathrm{Bu}$, bir ideoloji esas alınmak suretiyle kuki pozitivizmin gegersiz kulınmasının mūmkün olmaması demektir (Scarpelli, Cos'e, Böl. XIU-XIII).

Pozitif hukukun teorisi olan 'hukukun normatif teorisi de doktrinde eleştirilmektedir. Eleștiriler daha çok kelsençi dūşūnceyle ilgilidir (Örneğin, Maggiore. Normativismo 
normları olmadığını ve hukukçunun görevinin hukuku hukuk için ve gene hukukî araçlarla normatif önermeler đışında arama olduğunu savunan görüşler de bulunmaktadır. Bu görüşlere hukuk edebiyatında değişik isimler verilmiş olmakla birlikte, hukuk biliminin konusu ile ilgili düşüncelerindekj ortaklıktan ötürü hepsine birden 'hukukun sosyolojik teorisi' demek mümkündür ${ }^{98}$. Ancak, bu teorilerden 'Karaavrupast hukuk sistemlerinde' bu sistemin teorisi olan doktrinleri eleștirmek amacryla ortaya çıkanlarla, Anglo-Sakson ülkelerinde egemen hukuk sistemlerinin teorisi olan doktrinleri eșdeğer görmemek gerekir.

Esasen hukukun normatif ve sosyolojik teorileri hukuk bilimi alanında biri diğerine zıt iki temel düş̧ünce akımını temsil etmektedir. Aralarındaki ihtilafın esasını, hukuk biliminin gerçek konusunun ne

e antinormativismo nel diritto penale, Arch. pen. 1949, 1.) Maggiore'ye göre hukuk asgari ahlâktır. Ahlâk ise çözümünũ tanrı kavramında, yani dinde bulưr (Diritto penale. PG. V.1. TP. s. 16) Maggiore, bizce. hukuka bakıs açısında hukukçudan çok bir ideoloğ gibi davranmaktadır. Maggiorenin düșüncesinde pozitivsm reddedilmiştir. Oyleyse düşünürün hukukun normatif teorisini reddetmesi çok doğaldır, çünkü hukukun normatif teorisi bir hukuk ideolojisi degildir. Hukukun normatif teorisinin kurucusu kuşkusuz Kelsendir, Ancak, unutmamak gerekir ki, söz konusu teori Kelsenin bıraktığı yerde de kalmamıştır. O nedenle, Kelseni eleştirmek başka şey, hukukun normatif teorisine karşı çıkmak başka șeydir. Nitekinı, doktrinde, Kelseni eleștirdiği halde normativist olan hukukçu sayılnayacak kadar çoktur. Normatif teori, Kelsenci doktrinle ilgili görülerek, kimi markş̧ılarca da eleştirilmiştir (Öneğin. Capograssi, Inpressioni su Kelsen traddotto, Riv. Trim. dir. Pubb., 1952, s. 767 vd.; Nicolosi, Formalismo e storicismo del diritto, Riv. It. Sc. Giur., 1951, s. 293 vd). Bu marksçilara göre 'salt hukuk teorisi', yani bir anlamda hukukun normatif teorisì 'küçük burjuva konformizmi ideolojisinden' başka bir şey değildir. Oysa, Bobbio'dan edinilen bilgiye göre, hukukun normatif teorisi Rus hukuk doktrininde de taraftar bulmuştur ve savunulmaktadır (Bobbio, Studi sulla teoria generale, s. 98-104). Bu olgu da ortaya koymakmaktadır ki, hukukun normatif teorișine karşı kimi markş̧ılarca yöneltiten eleştirilere artık jtibar etmek pek mümkün görünmektedir. Hukukun normatif teorisi ve salt hukuk teorisi hakkındaki eleştirilerin ne oldugu ve bunların geçerli olup olmadıkları hakkında bkz. Treves, Perfezione, In Lineamenti di dottirina pura del dirito di Hans Kelsen, Torino, 1967, s. 10-30; ID. Introno alia concezione del diritto di Hans Kelsen, Riv. Int. Fil. Dir. 1952, s. 177 vd.; Bobbio. Studi sulla teoria generale, s. 75-107; ID. La teoria pura del diritto e sunoi critici Riv. Trim. di dir. e proc. civ., 1954.

* 'Içtimai müdafaa doktrini’, bize göre, pozitivist okulun bir uzantısından bașka bir şey deģildir. O nedenle adı geçen teori, pozitif hukukun bir teorisi deł̧il, hukukun bir sosyolojik teorisidir. Bu doktrin hakkında bilgi için bkz. Bettiol, Diritto penale, s. 479 vd.; Grispigni, Dirito venale, V. I.; Ferri, Sociologia criminale, Torinlo, $1930 \mathrm{~V}$. II; Ancel M., La nuova diffesa sociale, "Introduzione" Rassegna di studi penitensiario, 1967, Fasc., IV-V; Grammatica, Difesa sociale, Novissimo digesta, C.V, s. 635; Guarnieri, Diffesa sociale, Enciclopeđia del diritto, Milano, 1964, C. XII, s. 465; Nuvolone, Il principio della legalita e il principio della diffesa sociale, Scuola positiva, 1956; Yarsuvat D., Yeni içtimai müdafaa doktrini, IHFM., 1966. 
olduğu sorunu teşkil etmektedir. Bù, Karaavrupası hukuk sistemlerinde normatif teorinin eleștirisi olarak doğan teoriler yönünden de aynıdır. Gerçıkten, hukukun sosyolojik teorilerde hukukç̧unun görevi, doğrudan dogruya toplumsal deneye giderek, pozitif hukuku teșkil eden önermeleri bizzat bu đeneyin içinde aramaktır. Öyleyse, bu teorilerin modellediği hukukçu, hukuk normlarının bizzat mucididir. Buna karşllk, hukukun normatif teorisinde hukukģunun gọrevi, toplumsal deneyden normlar çtkarmak olmayıp, kendisine hukuken geçerli normlar olarak velilen hukuk normlarmı yorumlamaktır. Niormatif teoride hukukçu mucit değildir, sadece belli bir normatif sistemdeki hukuk normlarının kâşifidir. Sosyolojik teorilerde hukukçunun araştırma konusu, toplumsal deneyin bizzat kendisidir. Hukukçu bir toplum bilimci, yani sosyologdur ve hukuk bilimi burada hukuk sosyolojisi ile karıştırılmaktadır. Normatif teoride hukukçunun araştırma konusu, hukukun, yani pozitif hukukun kendisidir. $\mathrm{O}$ halde, hukukeu, kelimenin geleneksel anlaminda bir yorumcudur ve hukuk bilimi, zorunlu olarak pozitif hukukun bir teorisidir ve o nedenle hukuk sosyolojisinden ayrilmaktadir ${ }^{99}$.

Temelde biribirine karşıt bu iki grup teoriden Anglo-Sakson ülkelerinde carî hukukun sosyolojik teorisi ve Karaavrupası hukuk sistemlerinde cari bulunan hukukun normatif teorisi, esaslarl bakımından biribirinden çơk farklı iki deģișik hukuk sisteminin tezahürüdür. Hukukun kaynaklarının dinamik ve çoğulcu anlayışına yel veren hukukun Sosyolojik teorileri, Anglo-Sakson ülkelerinde cari hukuk sistemlerinin temel gerek ve karakterine cevap vermektedirler ${ }^{100}$. Buna karşıllk, normatif teori, Karaavrupası hukuk sistemlerinin geleneksel karakterini teşki] eden hukukun kaynağının "tekçi" anlayışına cevap vermektedir. Bu itibarla bu iki düşünce sistemi arasındaki köklü ihtilâf, cözümü mümkün salt teorik karakterde bir ihtilâf değildir, tam tẹrsine kendisini doguran gerçek durumlardan soyutlanmaksızın değerlendirilmesi gereken biribirine karșit hukuk ideolojilerinin ve farkh hukuk sistemlerinin karakterize ettiği tarihî kökenli bir ihtilâftır. O nedenle, söz konusu ihtilâfa kalkıp boșuboşuna kuramsal bir çözüm aramaya da gerek yoktur $^{\text {tot }}$. Durum bu olunca, Karaavrupası hukuk sistemlerinde halen ge-

Bobbio, Teoria della scienza, s. 100 yd.

100 Hukukun sosyolojik teorileri ve özellikle Anglo-Sakson hukukda geçerli 'hukuki realizm' akımı hakkında bkz. Bobbio, Teoria della norma, s. 60-70; ID. Teoria della scienza, s. 182-199; ID. Studi sulla teoria generale, s. 127-143; Kelsen, Lineamenti, s. 53 vd.; 180 vd.; Ross, Diritto e giustizia, s. 68 vd.; Aral, Hukaka ilișkin değjşik görüsller ve bunların değerlendiri!mesi ile birlikte doğru görülebilecek bir hukuk anlayışı, IOHFM. C. XXXIX, s.1-4; Gürkan, O. Hukuki realizm akım. Ankara, 1967:

Bobbio, Teoria della scienza, s. 181 
çetli hukuk teorisi de, geçen yüzylın sonlarında normatif teorinin eleştirisi biçiminde ortaya çıkan sosyolojik teorilerin etkin saldırısına rağmen $^{12}$, hukukun normatif teorisi olmaktadır. Karaavrupası hukuk sistemlerinde 'hukukçunun rolü' normatif teorinin etkinliğinin bir

102 Kara avrupasında 'tabii hukuk' ve 'hukukun normatif teorisine 'karşı çıan teorileri, önce de belirtildið̣̌i ūzere, hukukun konusu sorununu çözümlemedeki ortak yönlerinden ötürü, tek bir isim altında toplamak mümkündür. Bu teoriler "hukukun sosyolojik teorileri'dir. Bu grup içerisinde yer alan ve dar anlamdaki pozitif hukuk anlayışına karşı çıkan ilk grup teori, Sałigni'nin kurucusu olduğu 'tarihçi okul'dur (bkz. Abadan. Hukuk felsefesi, s. 260 vd). Tarihçi okula göre hukuk denilen şey 'rasyonel itkelerden' çlkmamıştur, torsine o ulustan doğan toplumsal ve tarihì bir olgudur. Oyleyse hukukun kaynağı doğa değil, ulusun ruhudur. Hukukun bu tür anlayışının sonuçları sunlar olmaktadır: Ne kadar ulus varsa, bir o kadar da hukuk vardır. Hukuk biliminin konusu, münhasiran, örf ve adet hukukudur, çünkü örf ve adet hukuku, bizzat toplumđan dogmaktadır. Hukukçunun görevi bu kuralları bulup ortaya çıarmaktır. Görüldüğ̃ üzere, romantik felșefenin bir ürünũ olan tarihçi okul, hukuk bilimini örf ve adet araștırmasına indirgediğinden hukuk bilimi sonunda sosyoloji bilimine indirgemiştir (Bobbio, Teoria della norma, s. 62). Geçen yüzyılda ortaya çıkan bir başka oku!, Geny, Contorowıcz, Erlich gibi hukukçuların, da dahil olđuğ 'özgür hukuk' teorisidir (Bkz. Grisostoni, Di alcuni recenti teorie sulle fonti e sulla interpretazione nel diritto privato, Frascati, 1904; Galdi, La suola del diritto liberao, Napoli, 1907; Di Carlo, Dei nuovi metodi di interpretazione del dirittor, Palermo, 1919.; Degni, L'interpretazione della legge, 2 ediz., Napoli, 1909; Coviello, L., Dei moderni metodi d'interpretazione della legge. 1908; Ferrara F., Potere del legislatore e funzione del giudice, Rriv. di. dir. civ. 1911). Bu akımın esasları, dar anlamdaki pozitivizmin eleştirisi sonunda ortaya çıkmıştır. Amac1, 'devlet hukuku' yerine 'toplum hukuku' ve 'yasama formüllerinde kriștalize olmuş hukuk' yerine 'yaşayan hukuku' yaratmaktır. Hukukçu bu akım taraftarlarına göre, devletçe konulan pozitif hukukun salt ve basit bir yorumcusu değildir ve böyle olmamalıdır. Hukukçu, devlet hıkukunun basit bir araşırıcısı, açıklayıcısı kurucusu ve sistemcisi sayılmamak gerekir. Hukukçu, toplumsal çatışma ve münasebetlerin doğrudan doğruya müşahadesinden hukuk kuralları çıkararak bizzat hukukun yaratıctsı olmak zorundadır. Görüldügũ üzere burada hukuk biliminin konusu artık pozitif hukukun bir incelemesi değildir. Bunun sonucu olarak. pozitif hukuk, hukuk araștırmasının zorunlu bir unsuru sayılmamaktadır. Hukuk kurallarının yaratılması, bu düşünce sisteminde, çözümünũ genellikle menfaatler yahut kavramlar içtihadında bulmaktadır. Menfaatler ictihadında hukuk biliminin konusu, toplumdaki menfaatler çatışması ve irade ihtilafları esasına göre beşeri davranışın hukuki kurallarını araşstırmaktır. $O$ halde, hukukçunun görevi, kanunun sadece basit bir mantıkî yorumu değil, aynı zamanda kanun koyucunun maksadında girmek ve menfaatler çatışması esas olmak üzere kanunları uygulamak ve kurallar koymaktır. Ancak, belirtmek gerekir $\mathrm{ki}$, bu faaliyet, kuralmsal bir faaliyet olmayı etik-siyasiideolojik bir faaliyettir. Zira, menfaatler çatsşması ve buna bağlı olarak irade ihtilafJarı esas alınarak beşeri ihtilafların hukuki çözümū daima bir değerlendirme sorununudur. Değerlendirme ise, mahiyetinin bir gereği, kuramsal deģil, etik-siyasi-ideolojik bir faaliyettir. Hukuk biliminin konusu ve hukuksunun faaliyeti, burada bir idolojiye indirgenmektedir. Gerçekten, hukukçunun faaliyeti, kendisini toplumsal olayların müşahadesi ve kurallaştırma amacına matuf geçerli kavramların teşkiliyle sıntrlandinlabilir. Bu faaliyet koskusuz bilimsel bir faaliyettir. Ancak, söz konusu faaliyet hukuk biliminin konusu olan bir faaliyet değil, hukuk sosyolojisinin konusu olan bir fa- 
sonucu olarak, hâlâ 'kanunların bir yorumcusu' rớlüdür ${ }^{103}$ ve hukukun normatif teorisi, bu hukuk sistemlerinde o sistemlerin gerekleri gözönünde tutularak oluşturulmuş bir teoridir. Böyle olunca bu teoriye kendisinde olmayan 'mutlak kuramsal bir değer' izafe etmek mümkünolmamak gerekir. Burada, olsa olsa, hukukun sosyolojik teorilerine cranla, hatta karaavrupası hukuk sistemlerinden farklı hukuk sistemleri karşısında, hukukun normatif teorisinin, đaha geçerli olduğu kanttlanabilir, ama asla bu teorinin mutlak kuramsal bir degeri haiz bulunduğu ileri sürülemez ${ }^{104}$. Buradan, en son tahlilde deneye dayalt da olsa, hukukun normatif teorisinin bir bilim olup olmadığı sorunu ortaya çıkmaktadır.

\section{Pozitif hukuk teorisi olarak hukukun normatif teorisinin bj- limliği soruna.}

Hukukun normatif teorisinin gerçekte bir bilim olup olmadığın saptamak için bu teorinin genel esaslarından hareket etmek gerekmektedir. Daha önce çeşitli vesilelerle açıklanmış olan bu esaslar kısaca şunlardır.

1. Hukukçunun, ceza hukukçusunun faaliyeti beşeri düşüncenin bir ürününün incelenmesine yöneldiğinden, hukuk bilïmi, manevi bilimler ailesi içerisinde yer almaktadır. O nedenle, hukuk araştırmasının, 'doğa alamine' değil 'kültür alemine' ait konularının karakterinden ötürü, doğa bilimlerinden farklı bilimlerle bazı ortak yönleri bulunmaktadır.

2. Hukuk, ceza hukuku araştırması veya hukuk' biliminin konusu olan 'manevi' veya 'kültürel' ürün, beşeri davranış kuralları bütünü veya normatif önermelerdir. Bu özellik, hukuk bilimini öteki manevi bilimlerden ayırmaktadır, çünkü inceleme konusunu teşkil eden öner-

faaliyettir. Konulan bu sınır aşlıp değerlendirme alanına girildiģinde, faaliyetin niteteliği artık ideolojiktir; o halde faaliyet kuramsal bir faaliyet olmaktan çıkmıştır. İşte menfaatler curisprüdanıı denen ve hukukun formalist anlayışına karşı çıan bu dūşünce sistemi, hukukun bir teorisi olmak amact ile ortaya çkmıs olmasına rağmen, sonunda hukukun bir teorisi dę̧il, doğrudan deneyin sınırlarını aşan biṛ idolojiye dönüșmekle amacından uzaklaşmış ve böylece pozitif hukukun bir teorisi olan normatikf teori karş1sında etkinližini koruyamamuştır. O nedenledir ki Karaavrupașı hukuk sistemleri yönünden tek gegerli hukuk teorisi bugün de herhalde pozitif hukukun bir teorisi olan hukukun normatif teorisidir (dipnottaki bilgiler için bkz. Bobbio. Teoria della scienza, s. 194 ve p. 6-7; ID. Teoria dellax, norma, p. 15; Kelsen, Lineamenti, s. 125; Grispigni, La dommatica giuridica, s. 29 vd.

10s Bobbio, Teoria della scienza, s. 182; Błkz. Nuvolone, I fini e imzezi nella scienza del diritto penale, Riv. It. di đir. pen., 1948, n. I-III, s. 39 vd.; Toroslu, Cürümlerin, s. 8; Aral, Hukuk ve hukuk bilimi, s. 136 vd.

104 Bobbio, Teoria della scienza, s. 182. 
meler, gerçek davranışlar üzerine ifadeler değil, mümkün veya farazi davranışlar üzerine kurulan ifadelerdir.

3. Hukuk ceza, hukuku araştırması en son tahlilde deneye dayalıdır, çünkü normatif önermelerin anlamlarının bilinmesi, bu önermelerin kendilerinden soyutlandığı gerçek davranıșlara gitmeyi, onlara başvurmayı gerektirmektedir. Bu niteliginden ötürü, hukuk bilimi, kendine özgüllüğ̈une rağmen, deneysel bilimler arasında yer almakta ve bu yüzden de formel bilimlerden ayrılmaktadu.

4. Hukuk ceza hukuku araştırmasının amacı, genel kavramlar. teşkil etmek, bu kavramlar arasındaki bağıntıları kurmak ve kavramların tutaılı tam bir sistemini inșa etmektir. Genel kavramların in\$̧aasına, münferit normatif önermelerin yorumuyla veya 'teleolojik' açıklamadan yararlanılarak bu önermelerin anlamlarının bilinmesiyle varılmaktadır. Bu özellik, hukukun "tabiatç" ve "tarihçi" anlayıșları karșısında, kesin bir tavır almaya imkân vermektedir, çünkü hukuk, ceza hukuku araştırması, konusuna nüfuz yöntemi (yorum) nedeniyle tarihçi, buna karșılık amacı (genelleştirme ve sistem) nedeniyle 'tabiatcı' tipte bir araşturma olmaktadır ${ }^{\text {tos }}$.

Demek ki, hukuk, ceza hukuku bilimi, hukukî normatif önermelerin, anlamlarının bilinmesi ve sisteminin teşkili için deneye dayalı bir araştırmasıdır. Bu tanımda, hukuk araștırmasında konu, normatif önermeler; esas, deney; metod, yorum; amac, sistem olmaktadır ${ }^{106}$.

Bu tür bir araştırma, acaba bilimsel midir, kısacası bilim midư ? Sorunun çözümü, bilim kavramına verilen anlam üzerinde, yani bilim kavramından ne kastedildiği üzerinde yoğunlaşmaktadır. Gerçekten, kimine göre ceza hukuku bir bilim değildir ve fakat normatif bir bilgi șubesidir. Zira ilim müșahadelerde bulunut, tespitler yapar ve kanuniyetlerin nelerden ibaret bulunduğunu gösterir. Ceza hukuku, ise muayyen bir takım kaideler ve normalar vaz etmekte ve bunlara bütün fertlerin riayet etmelerini ceza tehdidi ile emreylemektedir"107.

zos Bobbio, Teoria della scienza . s. 200-20I. Hukukun tabiatçı ve tarihçi anlayışları hakkında, Bobbio, Teoria della scienza, Böl. IV. s. 104-128:

106 Bobbio. Teoria della scienza, s. 201-202.

107 Örnȩ̧in, Dönmezer-Erman, Ceza Hukuku GK. C. 1., s. 11 : Ancak, düşünürlere göre ceza hukukunun koydurgu normlar akıl ile icat edilen, fayda ve lūzumluluğuna manttk yoluyla varılan bir takım rasyonel soyut düşüncelerin ifade tarzlarından ibaret değildir ve olmamalıdır Bu halter ... Sosyal hayattaki disiplin zorunluluğunun takibi olarak dogurduğu normlar nevinden olmalı ve Sosyal gerek ve zorumluluklara uygun olmalıdır.Bu itibarla, kaidelerin tespiti, normların meydana getirilmesi için yapılan çalışlışmalar bilimsel çabalardır' 
Buna karşılık, kimine göre, bilim eğer olaylar nizamını bilgiler nizamında aksettiren nesnel gerçeğin ekonomik ve sistematik bir tasnifyse kuşkusuz hukuk, ceza hukuku bilimi, bu anlamda bir bilim sayılmak gerekir, çünkü hukuk bilimi de, pozitif hukuk düzenini teșkil eden bühümlerin muhtevasını, bir bilgiler düzeni içerisinde aksettirmeyi amaçlamaktadır ${ }^{108}$. Görülïyor ki her iki anlayıș, genelde hukukun "normatifliğini: kabul etmekte, ama buradan farklı sonuçlara varmaktadırlar. Bu durumda, sorunun çözümünü, bize göre, bilim 'kavramının evrimi' sürecinde aramak gerekmektedir.

Bilginin 'pozitivist' ve 'akilcı' anlayışının egemen olduğu đönemlerde hukuk bilimi, kendine özgülüğü nedeniyle, genellikle bilimler sınıfına sokulamamıştır ${ }^{109}$. Ancak, bugün, bilime ve özellikle doğa bilimlerine verilen anlam, dünkünden, yani pozitivist ve akılcı anlayışın egemen olduğu dönemden tümden farklıdır. Hatta, denilebilir ki, hukuk biliminin bir bilim şubesi olup olmadığı yolundaki tartışmalara bugün yeni boyutlar gelmiștir ${ }^{10}$. Günümüzde bilimsellik anlayışı, klâsik akılcılık anlayışından farklı olarak genel esaslarını 'aklın' o halde 'gerçeğin izafiliği' kavramında bulmaktadır It!. Böylece, klâsik akılcılığın savunduğu temel kavramlardan 'aklın mutlaklığ' yerini

104 Örneğin, Toroslu, Cürümlerin, s. 10; Grispigni, Diritto, penale, C.I s. 10; Antolisei, Manuale, PG. s. 15: Ancak. Antolisei'e göre, hukuku inceleyen disiplin, kimilerinin istediği gibi, yalnızca bỉgi amacını gūden salt kuramsal bir đisiplin đeğildir. Pratik 'fonksiyonu'da vardır, çūnkü hâkime ve hâkimle birlikte çalışanlara, hukukun gereklerine daha çok cevap verecek bir biçimde kanunun uygulanması için 'kriterler' ha zırlamayı amaçlamaktadır. Bu düşüncenin eleștirisi için bkz; Toroslu, Cürūmlerin, s. 9; Grispigni, Diritto penale, C. I. s. 8.

tog Bu konuda bkz. Bobbio, Teotia della scienza, Cap. II, bzzellikle, p. 5-6. ve s. 202 vd. 1. Bu konuda bkz. Bobbio, Teoria della scienza, Cap. II, ozzellikle, p. 8 ve s. 204.

!" Bobbio, Teoria đella scienza, s. 207. Gerçekten, klâsik alkılctlık anlayışı, mutlak, salt bir akılculıktır. Bu anlayıs̆ta gerçek veya gerşekliğin en üstün organt akıl (ragione)dır. Ve akıldır kì insana gerçekliğe nüfuzz imkânt verir. Akıl madem būtūn insanlarda bir. dir, çûnkũ o insanın eseri değil insana bir vergidir, o halde gerçeklik veya gerçek de birdir. Baska bir deyimle akıl madem mutlaktır, o halde ak1l yoluyla çlkarlan gercek veya gerçeklik de mutlak gerçek veya mutlak gerçekliktir. Akılcilık, görūldügüü ủzere. tarihî insanı aşan, yani irdeleyen insanın dışında insana vergi bir şey olarak kabul edilen 'akll kavram' uzerine oturmaktadır. O nedenle, sadecel ama sadece insan, akla katıldığıından, aklın bir 'cüz' u' olduğundan, deneysel dưumun ötesine giden mutlak gerçekliğ seçme yeteneğgine sahiptir.

Aklın ve gerçekliğin bu anlayıșı, öte yandan, 'mantıŏın mutlaklığı, kavtamını zorunlu kılmaktadır. Burada, mantık, esaslarına göre aklın gerçekliği bulduğu kurallar būtūnŭ olarak evrensel ve zorunlu geçerliliği haiz bir kurallar mecmuasıdır. Oyleyse bu kurallar bütünū, farklı mantık-sistemlerinin olmadığ anlamında tek bir tanedir, Görüldūoùu

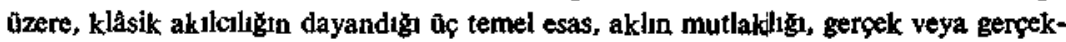

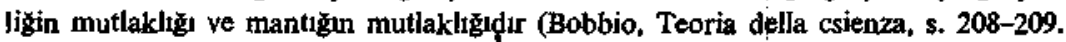
Akllcllk hakkunda bkz. Geymonat L., Studi per un nuovo razionalisma, Torino, 1945). 
'aklın yalnızca araçlığ', 'gerçeğin mutlaklığı' yerini 'gerçeğin itibariliğine'(*) ve 'mantığın mutlaklığı' yerini 'mantığn çoğulculuğu' kavramlarına bırakmışıı' ${ }^{112}$. Bu kavramlar, attık klâsik akılcılık anlayıșının tanıdığı bilim anlayışından tamamen farklı bir bilim anlayıșlna vücut vermektedirler. Bu bilim anlayıșı ise, yeni akılcılık akımının' bilim anlayışıdır ${ }^{13}$.

Yeni akılctlk akımında, bilimle, ilk (basit, jptidai) önermeleri ve önermelerinin değişim kuralları tam olarak belirlenmiş olan ve belli kurallar ve konmuş öncülerle (premersa) uyumlu bir biçimde işleyen bir önermeler sistemi kastedilmektedir. Böyle olunca

* 'Convensionalistica della verità' kavramını tam bir doğrulukla dilimize çevirmek mümkün olamamıştır. Bu kavramdan anlaşllan sey, "gerçeğin itibariliği" gerçeğin "herkesçe öyle kabul edilmesi”" "herkesin gerçek dediğinin gerçek saylmasi"dır.

$11^{2}$ Bobbio, Teoria della scienza, 4.210.

I' 'Yeni akılcılık', 'eleștirisel açkılculık' anlayışında, akıl, ne mutlak gerçeğin bilinmesinin yanılmaz organt, ne gerçeği gerçek olmayandan ayırabilmesi için insana lütfedilmiş bir tür ilăhi gơzdür; tersine, bir bilgi sorununu (kuransal bir sorun) koyma ye çözme için insanın yararlandığı akli bir kurallar bütünŭnư işaret etmektedir. Akıl, ihsan ediłmiş olan değişmez bir kudret değil, insan tarihi boyunca gelişip mükemmeleşen bir akji kurallar bütünüdür. $O$ halde akıl, insan oluşumunda meydana gelen insanca bir yetidir ve insan bilgisinin sınırlarıyla sınurlıdır. Evrenin bir parçası olan insan, evreni ne kadat çok tanırsa ve oyleyse ne kadar çok kuramsal sorunlar koyarsa, insanla koşut olan bu yeti de o kadar cok mūkemmelleşir. Akıl, akılcılığın bu tūr anlayışınđa, bir araçır, hatta đenebilir ki, 'teoretik insanın' en üstün aracıdır, insanın kendisiyle araştırma yaptığ bir araçtır. O nedenle o insana verilmiş đeğgildir, fakat insan tarafından teşkil edilmiştir. Akal bir kere verilmiş mükkemmel bir kudret değildir, tam tersine o, tıpkı bir makina, bir araç gibi sürekli mükemmelleşmektedir.

Aklın bu tür bir anlayışının sonucu olarak gerçekliğin mutlaklığı kavramı, yerini gerçekliẹin konvansiyonellił̧' kavramına bırakmıştır. Ancak. her bilimin ön gerçekliklerinin 'konvansiyonel' olmaları, onların keyfi olmaları, sadece bir oyın için saptanmı olmaları anlamina alınmamak gerekir. Zira, amaca uygunluk olarak akla uygunluk anlamını içermek kaydıyla onlar da akla uygun önermelerdirler. Böylece, aklın araçsallığ ve önermelerin konvansiyoneltiğinden, mantığın çoğulculuğ teorisi doğmaktadır tadır. Coğulçuluk, özünden ötürü, tek bir mantık değil, araștırmalara cevap veren farkłı mantıklar anlamındadır ve manttktan, araştırmalarımızı güden ve bir sonuca götüren akli kurallar bütŭnü anlaşılmaktadır. Öyleyse, mantık kutalları, sıkı sıkıya güttükleri araştırmayla bağımlıdırlar, demek ki kendilik!erinden geçerli değildirler. Buradan, mutlak bir mantık kuralları sisteminin tespit edilemeyeçğ, tersine her mantık kuralları sisteminin kendisinden çlktığ ve oluşumuna hizmet ettił̆i araştırmanan gözden uzak tutulmaksızın gözönüne alınmast gerektił̧i ortaya çıkmaktadır. Her araştırma, o halde, ön önermelerle birlikte, esaslarına göre başlanglc önermelerinin diğer önermelere deġişebileceğ veya esaslarına göre bizzat araştırmanın gelişmesine imkân veren bazı araștırma modellerinin hazırlandığ mantık kurallarınt da koymaktadır. Bu demektir kì, her araştırma için geçerli tek ve mutlak bir mantık kuralları sistemi değil, her arastırmanın kendine özgü olanbir mantık kuralları sistemi vardır (Buradaki bilgiler için bkz. Bobbio, Teoria della scienza. s. 206-213; Hançerlioł̆lu, Felsefe sözlüğü, İstanbul 1967). 
bir araştırmaya, artık gerçekliği muhtevi olmasından ötürü değil, ama kendisiyle ilerlediği doğruluktan $(=$ çelişmeżlik, tutarlıı, kesinlik, özgünlük) $=$ rigore) ötürü bilimsel denmektedir. Öyleyse aklın farklı bir anlayışı üzerine oturan modern metodolojide bilimselliği vurgulayan unsur, bu olușum dolayısıyla, gerçeklik kavramından doğruluk kavramına kaymıştır. Artık, bilimsel önermeler, farzedilen gerçegi veya ideal bir gerçekliği 'tecrübi bir operasyon' (fiil) veya 'idrak' (ide) ile tekrardan yapma anlamında kayıtsız şartsız gerçeğin ifadesi olduklarından bilimsel değildirler, tersine bizzat araştırmada tüm 'mantık' ve 'akliliğe' uyma anlamında doğru önermeler olduklatından bilimseldirler. Bir araştırmanın bilimselliği, demek ki, gerçeklikte, yani ifadenin nibaî ve kat'i biçimde ortaya çıkan 'nespel bir gerçekliğe' karşılık teşkil etmesinde değil, tersine anlatımmn (discorso) doğruluğunda, yani bizzat anlatımda kullanılan tüm terimlerin yeterli kat'jyetinde ve bir ifadenin kenđisi ile birlikte sistemi teşkil eden tüm öteki ifadelerle olan uyum ve tutarlılı̆gnda saklıdır ${ }^{114}$.

Gerçekten, belli bir araştırmanın içinde oluşacağı mantık kuralları ve ilk önermelerinin saptanmass eğer doğru bir anlatum yahut dilin teşkili için esaslar koymaksa, bilimsellik dilin doğruluğunda mündemiç olduğundan, doğru bir anlatımın teşkili dışında bilimsel her hangi bir araştırma mümkün değildir. $O$ nedenle, modern metodoloji, dil ve bilim arasındaki ilişki üzerinde ssrar etmektedir. Bilim, gerçekliğin bilinmesi veya 'vehminde' değil, tersine bilimsel dilin kullanılmasında mündemiçtir. Bir bilim teşkil etmek demek, doğru (= tutarl, kesin, özgün) bir dil teşkil etmek demektir. Teşkil olunan bu dilde, 'bilimsel gerçek' olarak geçerli olan önerme nesnel gerçekliğe adapte olan önerme değildir, fakat içine konulduğı sistem dahilinde geşerli kuralları gözeten terimlerle ifade edilen önermedir ${ }^{15}$. O halde bir anlatım veya bir dil ( $=$ linguaggio), a) sistemi teşkil eden 'ilk önermelerinn' tüm sözlerinin tanımlandığı veya bunların tüm kullanım kurallarmın saptandığı ve o kurallara uyulmadıkça asla kullanmanın mümkün olmadığı, b) ilk önermelerden esaslarına uyularak yeni önermelerin çlkarilmasını sağlayan kuralların tespit edildiği ve tespit edilen önermeler dışnda başka kuralların kullanılmadığı hallerde doğrudur ( $=$ tutarlıdır, kesindir, özgündũr) denebilmektedir. Bu da, bir önermeler sistemi ne kadar çok uyumlu ve çelişkisizse, o kadar bilimseldir demektir ${ }^{116}$.

Ancak, burada söz konusu edilen şey, bilimin basit bir dil işlemine indirgenmesi değildir. Aksine, yapılmak istenen, nesnel bilginin, açı-

"14 Bobbio, Teoria della scienza, s. 213-214

is Bobbio, Teoria della scienza, s. 215.

11. Bobbio, Teioria della scienza, s. 215. 
cası bilimin içinde mündemiç olduğı süjelerarası bilginin, en mükemmel biçiminin tanınıp bilinmesidir. Bu da, bir araştırmanın azamî veya asgari bilimsel niteliğinin 'alelade dil' ile yer değiștirerek bu dile üstün gelen dilin veya anlatımın azamî veya asgari doğruluğuyla bağımlı olduğu anlamina gelmektedir. $O$ halde, bilim, bilimsel dil denen dilin teşkiliyle, yani tamamen öznel bir bilgiden (bana ait bilgi) yüksek düzeyde 'süjelerarass' bir bilgiye çıkaran, yani nesnel bir bilgi yapan belli bir dille başlamakta ve bundan ötürü, bilim olmaları bakımından formel bilimlerle deneysel bilimler arasinda her hangi bir fark bulunmamaktadır ${ }^{17}$. Madem bilimsellik zorunlu olarak doğru bir dilin teşkilinden ibarettir, o halde, doğru bir dilin teşkili, bilim sıfatını kazanmak isteyen her araşturmanın tamamlayacağ 1 belli bir 'operasyonu' gerektirmektedir. Bu operasyon ise, genel bir deyimle, 'dilin analizi' (analisi del linguaggio) olmaktadır. Öyleyse, her bilim, bilimsel her araştırma, mutlaka dilin bir analizini zorunlu kılmaktadır ${ }^{118}$.

Bu anlamda, hukuk araştırması, acaba dilin bir analizini zorunlu kılmakta mıdır? Başka bir deyimle, hukukçunun yukarıda nitelikleri belirtilen faaliyeti, acaba bilimsel bir faaliyet midir? Sorunun çözümünü, hukuk araştırmasının veya hukukçunun faaliyetinin hukuk dilinin, yani normatif önermelerin bir analizini zorunlu k1lp kılmadı̆̆ında aramak gerekir. Hukuk araştırması, tıpkı diğer araştırmalar gibi, kuşkusuz dilin bit analizini zorunlu kılmaktadır. Hukuk araştırmasının konusu, yani tahlil edilecek dil, sadece bir hukuk düzenini teșkil eden normatif önermelerdir. Normatif önermeler, mahiyetinin gereği olarak, belli bir dilde ifadesini bulan ve uygulaması gerekli görülen belli davranışlar hakkındaki ifadelerden başka bir şey değildir. o nedenle hukukçu da, araştırmasında, bizzat ataştırmasının bu konusundan ötürü dilin bir analizine gitmekten vazgeçmez, çünkü araştırmasının başııca konusu, bizzat kanun koyucunun dilidir. Hukuk araştrrmas1, o halde, temel bölümleri ve eleştirisel görünümünde, kanun dilinin bir analizinde çözümlenmektedir. Bu demektir ki, hukuk araştırmasının amacı, her araştırma dilin bir analizi olduğundan, her bir bilimin teşkiliyle birlikte gelen öteki dil analizleriyle aynı ofmak zorundadır. Bu amac, doğru bir dil olarak, bilimsel bir dil olarak, bir hukuk dilinin teşkilidir. Açıkcası, kanun koyucunun anlatımı, yani normatif anlatım karşısında hukuk biliminin tavrı, diğer bilimlerin, fizik, matematik vs., anlatımlan karșısındaki tavırının aynıdır. $O$ anlamda ki, ötcki bilimlerden farksız olarak, hukuk bilimi de, kanunun veya kanun koyucunun dilini, doğru bir dile tahlville zorunludur. Bu

117 Bobbio, Teoria della scienza, s. 216-217.

118 Bobbio, Teoria delia scienza, s. 217. 
da, her halde bu dilden doğru bir dilin teşkili başarılabildiği ve teşkil olunan dilin sınırlar içerisinde kalındığı takdirde, hukuk araștırmasının bilimsel bir araştırma, kısacası bir bilim olduł̆ unun söylenebileceği anlamına gelmektedir ${ }^{139}$.

\section{Sonuç.}

Madem bilim dilin doğru bir teșkilidir, pozitif hukukun bir teorisi olan hukukun normatif teorisi, normatif ifadelerden normatif dilin doğru bir teșkili olduğundan, konusu ve metodu özellik de gösterse, bir bilimdir ve bilim olma bakımından öteki bilimlerden hiç de farklı değildir.

1:9 Bobbio, Teoria della scienza, s. 218 vd. 